\title{
Retrieval of stratospheric and tropospheric BrO columns from multi-axis DOAS measurements at Reunion Island $\left(21^{\circ} \mathrm{S}, 56^{\circ} \mathrm{E}\right)$
}

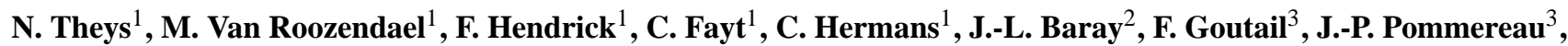 \\ and M. De Mazière ${ }^{1}$ \\ ${ }^{1}$ Belgium Institute for Space Aeronomy (IASB-BIRA), Brussels, Belgium \\ ${ }^{2}$ Laboratoire de L'Atmosphère et des Cyclones (LACy), UMR-CNRS, St-Denis, La Réunion, France \\ ${ }^{3}$ Service d'Aéronomie, Verrières-le-Buisson, France
}

Received: 16 May 2007 - Published in Atmos. Chem. Phys. Discuss.: 14 June 2007

Revised: 3 September 2007 - Accepted: 13 September 2007 - Published: 18 September 2007

\begin{abstract}
Spectral measurements of $\mathrm{BrO}$ using zenithsky and off-axis viewing geometries are combined in a linear multiple regression retrieval algorithm to provide stratospheric and tropospheric $\mathrm{BrO}$ vertical columns. One year of measurement data are investigated over Reunion-Island $\left(20.9^{\circ} \mathrm{S}, 55.5^{\circ} \mathrm{E}\right)$, from August 2004 to June 2005. A comparison between the stratospheric columns retrieved at $45^{\circ}$, $80^{\circ}, 85^{\circ}, 87.5^{\circ}$ and $92.5^{\circ}$ solar zenith angles and photochemical simulations initialized by chemical fields from the 3-D-CTM SLIMCAT and further constrained by observed $\mathrm{NO}_{2}$ profiles shows a good agreement only by considering a contribution from the very short-lived organic bromine substances to the stratospheric inorganic bromine budget, of 6 to 8 pptv. Furthermore, stratospheric $\mathrm{BrO}$ profiles retrieved from late twilight zenith-sky observations are consistent with a total inorganic bromine $\left(\mathrm{Br}_{\mathrm{y}}\right)$ loading of approximately $23 \mathrm{pptv}$. This represents 6 to $7 \mathrm{pptv}$ more than can be supplied by long-lived organic bromine sources, and therefore supports an added contribution from very shortlived organic bromine substances as recently suggested in several other studies. Moreover strong evidences are presented for the existence of a substantial amount of $\mathrm{BrO}$ in the tropical free-troposphere, around $6 \mathrm{~km}$ altitude, possibly supplied by the decomposition of short-lived biogenic bromine organic compounds. Tropospheric $\mathrm{BrO}$ vertical columns of $1.1 \pm 0.45 \times 10^{13} \mathrm{molec} / \mathrm{cm}^{2}$ are derived for the entire observation period. Comparisons between ground-based $\mathrm{BrO}$ vertical columns and total $\mathrm{BrO}$ columns derived from SCIAMACHY (onboard the ENVISAT satellite) nadir observations in a latitudinal band centered around $21^{\circ} \mathrm{S}$ present a good level of consistency, which further strengthens the conclusions of our study.
\end{abstract}

Correspondence to: $\mathrm{N}$. Theys

(theys@aeronomie.be)

\section{Introduction}

Inorganic bromine $\left(\mathrm{Br}_{\mathrm{y}}=\mathrm{Br}, \mathrm{BrO}, \mathrm{BrONO}_{2}, \mathrm{HBr}, \mathrm{HOBr}\right.$, $\mathrm{BrCl})$ is the second most important halogen that affects stratospheric ozone. Although much less abundant than chlorine, stratospheric bromine presently contributes to the global ozone loss by about $25 \%$, owing to its much larger ozone depletion potential relative to chlorine (e.g. WMO, 2003, and references therein). During daytime the most abundant inorganic bromine species is $\mathrm{BrO}$, which represents 30 to $70 \%$ of total $\mathrm{Br}_{\mathrm{y}}$. $\mathrm{BrO}$ is also the only compound within the $\mathrm{Br}_{y}$ family to be measured routinely (e.g. Wagner et al., 1998; Richter et al., 1998; Van Roozendael et al., 1999; Hausmann et al., 1994; Schofield et al., 2004a; Pundt et al., 2002; Dorf et al., 2006a, Sinnhuber et al., 2002, 2005; Sioris et al., 2006). The sources of inorganic bromine in the stratosphere originate from naturally and anthropogenically emitted bromine-containing organic gases. Long-lived organic species are transported into the stratosphere with a time delay of approximately 3 to 4 years, before being converted into inorganic forms by photolysis or reaction with $\mathrm{OH}$ radicals. Until recently, the $\mathrm{Br}_{\mathrm{y}}$ mixing ratio was generally assumed to be negligibly small below and at the tropopause while rapidly increasing with altitude up to about $25 \mathrm{~km}$ where full conversion into inorganic forms is achieved. Based on a budget of the long-lived natural $\left(\mathrm{CH}_{3} \mathrm{Br}\right)$ and anthropogenic $\left(\mathrm{CH}_{3} \mathrm{Br}, \mathrm{CBrClF}_{2}, \mathrm{CBrF}_{3}, \mathrm{CBrF}_{2} \mathrm{CBrF}_{2}, \mathrm{CBr}_{2} \mathrm{~F}_{2}\right)$ organic bromine source gases observed over the last decade (Wamsley et al., 1998), the stratospheric $\mathrm{Br}_{\mathrm{y}}$ loading is currently estimated to be about $16-17$ pptv. However, several recent studies (Pundt et al., 2002; Salawitch et al., 2005; Sioris et al., 2006; Sinnhuber et al., 2002, 2005; Schofield et al., 2004a; Dorf et al., 2006a, b) have suggested that an additional contribution of about $5.6 \pm 2$ pptv must be considered, due to bromine release from short-lived biogenic organic compounds (such as $\mathrm{CHBr}_{3}, \mathrm{CH}_{2} \mathrm{Br}_{2}, \mathrm{CH}_{2} \mathrm{BrCl}, \mathrm{CHBr}_{2} \mathrm{Cl}$,

Published by Copernicus Publications on behalf of the European Geosciences Union. 
$\mathrm{CHBrCl}_{2}, \mathrm{CH}_{2} \mathrm{BrCH}_{2} \mathrm{Br}$ ) or even the direct intrusion of inorganic bromine from tropospheric origin into the lower stratosphere. Inorganic bromine compounds may be produced and sustained in the free troposphere due to the decomposition of short-lived organic bromine compounds under the action of heterogeneous and/or gas-phase photochemical reactions. This is supported by recent observations from space (Pundt et al., 2000; Van Roozendael et al., 2002; Richter et al., 2002), the ground (Hendrick et al., 2007) and balloons (Fitzenberger et al., 2000), all suggesting although with large uncertainties the widespread presence of $\mathrm{BrO}$ in the troposphere, with mixing ratios in the range from 0.5 to $2 \mathrm{pptv}$ if uniformly mixed. Elaborating on these observations, recent modeling results (von Glasow et al., 2004; Lary, 2005; Yang et al., 2005) have highlighted the possible role of tropospheric halogens (in particular bromine) as an additional sink for ozone, a process so far largely ignored. These studies suggest that bromine might be responsible for a reduction in the zonal mean $\mathrm{O}_{3}$ mixing ratio of up to $18 \%$ and locally even up to $40 \%$. In Polar Regions, additional amounts of inorganic bromine are seasonally released in large quantities in the boundary layer during spring due to the so-called Polarbromine explosion phenomenon (Hausmann and Platt, 1994; Kreher et al., 1997; Hönninger and Platt, 2002; Frieß et al., 2004). These emissions are responsible of complete ozone depletion events (ODEs) in the polar boundary layer. A comprehensive review of the role of bromine species in the polar ODEs can be found in Simpson et al. (2007). Although in smaller quantities, boundary layer $\mathrm{BrO}$ emissions have also been identified over salt lakes (Hebestreit et al., 1999), as well as in the marine boundary layer (Leser et al., 2003) and in volcanic plumes (Bobrowski et al., 2003).

Here we present an advanced retrieval method enabling the simultaneous determination of both tropospheric and stratospheric BrO vertical columns, based on multi-axis DOAS (MAXDOAS) UV-visible observations. By combining in a retrieval scheme measurements of the scattered sky light acquired from noon to twilight in different viewing elevations (from the horizon to the zenith) and making use of the change in sensitivities associated to the different observations geometries, the vertical distribution of the $\mathrm{BrO}$ concentration can be inferred. The analysis explicitly takes into account the effect of the $\mathrm{BrO}$ photochemical variations, in particular for the simulation of the radiative transfer at twilight when photochemical gradients along the slant stratospheric photon path are important. The retrieval algorithm has been applied to observations performed from August 2004 to June 2005 at Reunion Island $\left(20.9^{\circ} \mathrm{S}, 55.5^{\circ} \mathrm{E}\right.$, Indian Ocean), a latitude where currently available $\mathrm{BrO}$ observations are very sparse. It has been recently argued that biogenic short-lived organic compounds (e.g. $\mathrm{CHBr}_{3}$ ) that are mainly released by oceans could be rapidly transported in the UT/LS region under the action of the strong tropical convection. This highlights the importance of tropics in determining the stratospheric bromine budget as pointed out by several authors
(Salawitch 2006; Carpenter et al., 2000; Yang et al., 2005; Sinnhuber et al., 2005).

The paper is organized in four parts. After a short description of the instrumental setup in Sect. 2, the methodology applied to retrieve stratospheric and tropospheric $\mathrm{BrO}$ vertical columns is detailed in Sect. 3. This section also includes a quantitative discussion of the information content of the retrieval according to Rodgers (2000) as well as a comprehensive error budget. This is followed in Sect. 4 by a presentation of the results and their discussion in the light of our current understanding of bromine photochemistry in the atmosphere. Conclusions are given in Sect. 5.

\section{Instrument}

Measurements have been performed using a multi-axis DOAS (MAXDOAS) spectrometer designed and assembled at IASB-BIRA. This instrument was continuously operated on the roof of the LPA (Laboratory of Atmospheric Physics) building of the University of Saint-Denis, La Réunion $\left(20.9^{\circ} \mathrm{S}, 55.5^{\circ} \mathrm{E}\right)$ from August 2004 to June 2005, except from 25 March to 28 April when the container had to be dismantled due to a strong tropical storm event. The instrument consists of a grating spectrometer from Acton Research Corporation (ARC SpectraPro 275) installed inside a watertight thermoregulated case and connected through a fiber optic bundle to an entrance telescope having a field of view of approximately $1^{\circ}$ full angle. The telescope is itself connected to a rotating mirror allowing viewing elevation angles to be scanned from $3^{\circ}$ above the horizon up to the vertical at zenith. The optical head faces the sea towards the North direction. The control of the acquisition cycle including the positioning of the pointing mirror, the optimization of the exposure time to ensure adequate photon filling of the CCD detector and the spectral acquisition is fully automated, one complete scan of all elevation angles $\left(3^{\circ}\right.$, $6^{\circ}, 10^{\circ}, 18^{\circ}$, zenith) requiring approximately $15 \mathrm{~min}$. The spectrometer has a focal length of $275 \mathrm{~mm}$ and is mounted with a ruled grating of 600 grooves $/ \mathrm{mm}$ covering a spectral window from $300 \mathrm{~nm}$ to $450 \mathrm{~nm}$. It is equipped with a $1340 \times 400$ back-illuminated CCD detector from Roper Scientific (NTE/CCD-400EB), cooled to $-40^{\circ} \mathrm{C}$ using a triple stage Pelletier system. Recorded scattered light spectra have a resolution of $0.75 \mathrm{~nm}$ FWHM and a sampling ratio of 7 pixels/ FWHM. At twilight, the instrument switches from the full multi-axis viewing mode to a dedicated stratospheric mode where only zenith-sky measurements are taken. In this mode, the time sampling and the signal to noise ratio of the twilight zenith-sky observations are optimized in view of the inversion of stratospheric columns and profiles (see Hendrick et al., 2004). 


\section{Data analysis}

The data analysis involves two main steps. First, the total slant column amount of $\mathrm{BrO}$ is determined for each viewing direction according to the DOAS technique. Second, model simulations of the $\mathrm{BrO}$ slant column obtained from coupled radiative transfer and photochemical model calculations are adjusted to the observations until a consistent stratospheric and tropospheric $\mathrm{BrO}$ vertical column solution is obtained that matches all viewing directions.

\subsection{DOAS slant column retrieval}

The measured spectra are analysed using the Differential Optical Absorption Spectroscopy technique (Platt, 1994). This method relies on the assumption that one effective photon path can be defined, which represents in average over the fitting interval the complex path of scattered photons in the atmosphere. For optically thin conditions in the UV-visible region this assumption is largely verified, which implies that the absorption by atmospheric trace gases along the effective slant path of measured photons can be treated in a simple way using the Beer-Lambert law. In practice, atmospheric absorbers (in particular $\mathrm{BrO}$ ) are separated using the characteristic differential structures of their absorption cross-sections determined from laboratory measurements. Since in most cases several absorbers display absorption structures in the same wavelength interval, the inversion process requires that all relevant interfering absorption features be taken into account. In the case of $\mathrm{BrO}$, the spectral interval that optimizes the sensitivity to the target differential absorption structures while minimizing interferences with other absorbers is in the range from 345 to $359 \mathrm{~nm}$. Further details on the optimization of this fitting interval are given below. The spectral evaluation consists in a least-squares fit procedure where cross-sections of $\mathrm{BrO}(228 \mathrm{~K})$ (Wilmouth et al., 1999), ozone (223 K and $243 \mathrm{~K}$ ) (Bogumil et al., 2003), $\mathrm{NO}_{2}$ (220 K) (Vandaele et al., 1997), HCHO (293 K) (Meller and Moortgat, 2000 ), and the collision pair of oxygen molecules $\mathrm{O}_{4}$ (Greenblatt et al., 1990) are adjusted to the log-ratio of a measured and a reference spectrum usually taken at noon in zenithsky geometry. The quantity retrieved with this method is a so-called differential slant column density (DSCD), which is the difference of the column amount of the absorber along the light path and the absorber amount in the reference spectrum. The residual broadband features due to Rayleigh and Mie scattering are removed using a third order closure polynomial. To match the spectral resolution of the instrument, the laboratory absorption cross-sections are convolved using the measured slit function at $346.6 \mathrm{~nm}$. In the case of the strongest absorbers ozone and $\mathrm{NO}_{2}$, a correction for the so-called solar $\mathrm{I}_{0}$ effect (Aliwell et al., 2002; P. V. Johnston, unpublished results) is further applied. The wavelength calibration of the measured spectra is accurately determined by reference to the high-resolution solar atlas of
Kurucz et al. (1984), according to the procedure described in Van Roozendael et al. (1999). To correct for the Ring effect (Grainger and Ring, 1962) a pseudo absorption crosssection generated after Vountas et al. (1998) using the SCIATRAN radiative transfer model (Rozanov et al., 2001) is included in the fit. Similar settings are used for the retrieval of $\mathrm{O}_{4}$ DSCDs except for the fitting interval, which is slightly shifted towards longer wavelengths $(338.5-364.5 \mathrm{~nm})$ in order to capture the strong $\mathrm{O}_{4}$ absorption band centered at $360 \mathrm{~nm}$.

Due to the faintness of the $\mathrm{BrO}$ differential absorption features (typically smaller than $0.1 \%$ of absorbance) and the presence of much stronger interfering absorption bands from ozone in the same wavelength region, the retrieval of $\mathrm{BrO}$ DSCDs is generally difficult and requires careful treatment. Main sources of uncertainties including those related to instrumental parameters (wavelength calibration, spectral stray light, slit function, etc.), the temperature dependence of the ozone absorption cross-sections or the impact of the solar $\mathrm{I}_{0}$ effect have been addressed in the literature leading to a set of recommended $\mathrm{BrO}$ retrieval settings (see e.g. Arpag et al., 1994; Richter et al., 1999; Aliwell et al., 2002). In the present work, the problem of the optimization of the wavelength interval used for $\mathrm{BrO}$ retrieval has been revisited. As already mentioned the fitting interval is usually determined empirically in an attempt to maximize the sensitivity to the target gas and at the same time minimize interferences with other absorbers. In the case of $\mathrm{BrO}$, the main difficulty comes from the unavoidable presence of strong interfering ozone absorption bands. At twilight, the ozone absorption becomes so large that the optically thin approximation used in the DOAS technique may not be fully satisfied, leading to systematic misfit effects that may introduce biases in the retrieved $\mathrm{BrO}$ DSCDs.

In order to assess the importance of such effects, simulations of the zenith-sky radiance have been performed using the SCIATRAN model (Rozanov et al., 2001) and used to test different choices of fitting intervals. Radiative transfer calculations were performed in the $340-360 \mathrm{~nm}$ interval for a range of solar zenith angle values (50-92 degrees) and considering absorption by all relevant trace gases. Rotational Raman scattering by molecular oxygen and nitrogen (i.e. the main source of the Ring effect) was also explicitly included (Vountas et al., 1998). In order to simulate the impact of the solar $\mathrm{I}_{0}$ effect, calculations were realized at the resolution of $0.1 \mathrm{~nm}$, further convolved to the instrumental bandpass $(0.7 \mathrm{~nm}$ FWHM $)$ and finally resampled on the wavelength grid of the field instrument. Based on this set of synthetic spectra, test retrievals were conducted in various wavelength intervals and the resulting BrO DSCDs were compared to the reference DSCDs calculated from the radiative transfer model at the wavelength of $352 \mathrm{~nm}$ (reference wavelength used for $\mathrm{BrO}$ air mass factor calculations, see Sect. 3.2). Results from these sensitivity tests are displayed in Fig. 1a for three typical intervals recommended in the literature. As can 

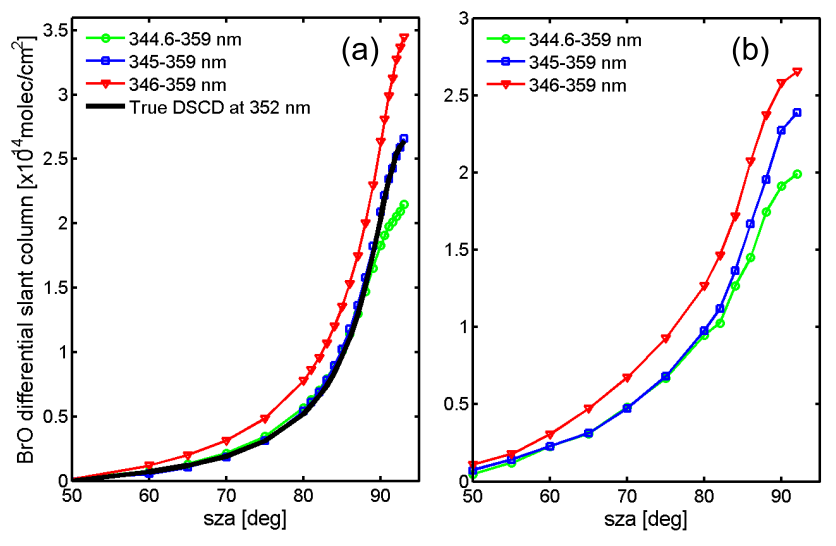

Fig. 1. BrO differential slant columns (DSCDs) retrieved in different wavelength intervals from (a) simulated radiances generated using the SCIATRAN model, and (b) actual zenith-sky observations performed at Reunion Island. Reference DSCDs calculated at $352 \mathrm{~nm}$ from the model are plotted with a thick black line.

be seen, differences as small as a few tenths of a $\mathrm{nm}$ in the selection of the shorter wavelength of the interval (where ozone absorption is strongest) can have a very significant impact on the BrO DSCD. Our simulations strongly suggest that the $345-359 \mathrm{~nm}$ interval efficiently minimizes the bias on the retrieved $\mathrm{BrO}$ columns in the full range of solar zenith angles. This interval has therefore been selected as a baseline for the present study. As an additional verification, the test fitting windows have also been applied to actual $\mathrm{BrO}$ measurements (see Fig. 1b). Although the shape of the observed $\mathrm{BrO}$ DSCD variation cannot be precisely captured by the simulations due to the non-inclusion of $\mathrm{BrO}$ photochemical effects in the SCIATRAN version used here (version 1.2), one can see that both synthetic and actual retrievals display similar dependences on the fitting interval, which reinforces our confidence in the reliability of the simulations.

\subsection{Inversion of stratospheric and tropospheric columns}

As already mentioned, the quantity retrieved by the DOAS technique is the differential slant column density, which corresponds to the trace gas concentration integrated along the effective light path of scattered photons. Since the light that reaches the instrument travels through the entire atmosphere from top to bottom, the measured BrO DSCD will contain absorption originating from both stratospheric and tropospheric altitudes (provided of course that sizeable amounts of $\mathrm{BrO}$ do exist in both regions). In order to separate the stratospheric and tropospheric contributions, it is necessary to combine observations displaying different sensitivities to the various atmospheric layers. In this work, we first exploit the geometrical path enhancement characteristic of scattered light measurements at twilight to get information on the stratospheric part of the $\mathrm{BrO}$ profile in a way similar to that used in vertical profiling studies (e.g. Preston et al., 1997; Schofield et al., 2004a, b; Hendrick et al., 2004). Second MAXDOAS observations performed at $3^{\circ}, 6^{\circ}, 10^{\circ}$ and $18^{\circ}$ of elevation above the horizon are combined with zenith-sky measurements to infer additional information on the tropospheric part of the $\mathrm{BrO}$ profile. The geometrical light path enhancement at low viewing angle elevation is such that the sensitivity to trace gas absorptions occurring in the atmospheric boundary layer can be increased by an order of magnitude (see e.g. Wagner et al., 2004; Wittrock et al., 2004).

The inversion method applied here is based on an analysis of the diurnal evolution of the measured $\mathrm{BrO}$ differential slant column, which is assumed to be well represented by the following equation:

$$
\begin{aligned}
& \operatorname{DSCD}(\theta(t), \varphi(t), \phi)+\operatorname{RSCD} \\
& \quad=\operatorname{VCD}_{\text {strato }}(\theta(t)) \mathrm{AMF}_{\text {strato }}(\theta(t), \varphi(t)) \\
& \quad+\operatorname{VCD}_{\text {tropo }}(\theta(t)) \operatorname{AMF}_{\text {tropo }}(\theta(t), \varphi(t), \phi)
\end{aligned}
$$

Where VCD is the vertical column, AMF the air mass factor, $\theta$ the solar zenith angle (SZA), $\varphi$ the relative azimuth angle between the sun and the viewing direction and $\phi$ the viewing elevation angle. RSCD represents the residual slant column density in the reference spectrum, derived as explained in Sect. 4.2. As a result of the photochemically induced diurnal variation of $\mathrm{BrO}$, the stratospheric and tropospheric VCDs depend on the SZA, while the AMFs depend on both viewing and solar zenith angles. Note that the stratospheric AMF can be considered with a good level of approximation as independent of the viewing angle. Photochemical effects, mostly important at twilight, are explicitly treated in the inversion process, as further explained below.

The air mass factors $\mathbf{A} \mathbf{M} \mathbf{F}_{\text {tropo }}$ and $\mathbf{A} \mathbf{M} \mathbf{F}_{\text {strato }}$ represent the enhancement of the absorption along the light path with respect to the vertical path, in the troposphere and the stratosphere respectively. In the present analysis, a tropopause height of $16 \mathrm{~km}$ characteristic of tropical regions has been considered, in agreement with temperature profiles from the European Centre for Medium-Range Weather Forecasts (ECMWF). The AMFs can be determined through appropriate calculation of the transfer of the solar radiation in a multiple scattering atmosphere. In addition photochemical effects that introduce spatial and temporal gradients in the $\mathrm{BrO}$ concentration field must be taken into account, especially for twilight conditions. In this work, forward model calculations of the $\mathrm{BrO}$ absolute slant columns (SCD) and corresponding AMFs have been obtained using the pseudo-spherical radiative transfer model (RTM) UVSpec/DISORT (Mayer and Kylling, 2005) coupled to the stacked photochemical box model PSCBOX (Errera and Fonteyn, 2001; Hendrick et al., 2004). The PSCBOX model includes 48 variable species, 141 gas-phase photochemical reactions and is initialized at 20 independent altitude levels with 00:00 UT pressure, temperature and chemical species profiles from the 3-D chemical transport model (CTM) SLIMCAT (Chipperfield, 1999, 
2006; see also Sect. 4.3). A stratospheric inorganic bromine total loading of $21.2 \mathrm{pptv}$, accounting for long-lived sources $\left(\mathrm{CH}_{3} \mathrm{Br}\right.$ and halons, WMO 2003) and an additional contribution of 6 pptv from short-lived bromine compounds, has been assumed within the SLIMCAT model. Updated kinetic and photochemical data are taken from the JPL 2006 compilation (Sander et al., 2006). As investigated in Fietkau et al. (2007), the reaction $\mathrm{BrONO}_{2}+\mathrm{O}\left({ }^{3} \mathrm{P}\right)$ can play an important role in the tropical stratosphere and has thus, been included in the model simulations. The results of the photochemical model are given at chemical time steps of $6 \mathrm{~min}$.

Model $\mathrm{BrO}$ profiles are supplied to the RTM code, and used to compute the AMFs. The UVSpec/DISORT model has the capability to ingest two-dimensional arrays (altitude and SZA) of BrO concentration fields so that the impact of photochemical changes along the incident light path can be accounted for in the calculations (see e.g. Fish et al., 1995). This particular feature of the model has been recently validated as part of a dedicated RTM intercomparison (Hendrick et al., 2006). As already mentioned, BrO AMFs have been calculated at the wavelength of $352 \mathrm{~nm}$ (center wavelength of the applied DOAS fitting interval), for a fixed albedo of $6 \%$ which has been found to be typical for sea-surface conditions (Koelemeijer et al., 2003).

Following Schofield et al. (2004a, b) and in order to limit the number of retrieval parameters, we have assumed that six profiles given, respectively, at $45^{\circ}, 80^{\circ}, 85^{\circ}, 87.5^{\circ}$ and $92.5^{\circ}$ of SZA describe adequately the diurnal variation of $\mathrm{BrO}$ in the stratosphere. The stratospheric VCDs can be determined at other SZAs using simple linear interpolations. The vertical distribution of $\mathrm{BrO}$ being largely unknown in the troposphere, our baseline for the retrieval has been to assume a free-tropospheric profile consistent with the observed profile of Fitzenberger et al. (2000). This assumption will be further tested in Sect. 4.4, where attempts to derive the vertical distribution of $\mathrm{BrO}$ in the troposphere from multi-axis DOAS observations are presented. Since no measurements of the diurnal variation of $\mathrm{BrO}$ in the troposphere are currently available, we have adopted the approach introduced in Schofield et al. (2004a, b). This consists in assuming a tropospheric $\mathrm{BrO}$ diurnal variation similar to the one modeled in the lowest levels of the stratosphere. It will be shown later that inversion results are weakly dependent on this assumption.

The inversion for the stratospheric and tropospheric $\mathrm{BrO}$ VCDs is obtained by fitting Eq. (1) to a set of measurements recorded from noon to twilight at various elevation viewing angles and solar zenith angles. Morning and afternoon measurements are treated separately. For the stratospheretroposphere separation, the technique takes benefit of the different evolution of the stratospheric and tropospheric AMFs as a function of SZA. This is illustrated in Fig. 2 for typical conditions in the zenith-sky geometry. In the inversion process, the stratospheric BrO VCDs are simultaneously (and independently) retrieved at five values of the SZA $\left(45^{\circ}\right.$,

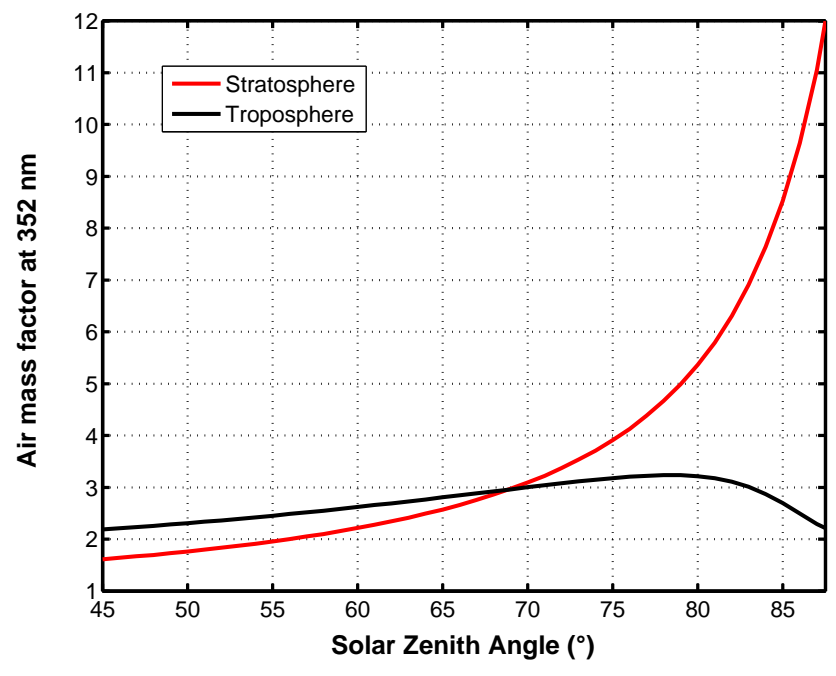

Fig. 2. Stratospheric and tropospheric $\mathrm{BrO}$ air mass factors calculated at $352 \mathrm{~nm}$ in the zenith-sky viewing geometry. The enhancement of the sensitivity to stratospheric $\mathrm{BrO}$ at twilight is obvious.

$80^{\circ}, 85^{\circ}, 87.5^{\circ}$ and $92.5^{\circ}$ ) meaning that the diurnal variation of the stratospheric $\mathrm{BrO}$ column is actually retrieved from the observations and not forced a priori from photochemical model calculations. Note that photochemical calculations are in fact only used to ensure proper calculation of the late twilight AMFs when two-dimensional gradients of the $\mathrm{BrO}$ concentration are important.

Since the introduction of an extra retrieval parameter for the slant column in the reference spectrum (RSCD in Eq. 1) can lead to unwanted uncertainties and retrieval instabilities, RSCD has been determined prior to the inversion as described in more details in Sect. 4.2.

\subsection{Averaging kernels}

In this section the capacity of the inversion method to separate adequately the stratospheric and tropospheric signals from the observations is addressed, based on the concept of the averaging kernels as developed in (Rodgers, 2000). The averaging kernel represents the sensitivity of the retrieval to the true state:

$A=\frac{\partial \hat{x}}{\partial x}$

where $\hat{x}$ is the retrieved state vector (i.e. here the tropospheric and stratospheric VCDs) and $x$ represents the true $\mathrm{BrO}$ vertical profiles. Equation (2) can also be written:

$A=\frac{\partial \hat{x}}{\partial y} \frac{\partial y}{\partial x}=G \frac{\partial y}{\partial x}$

where $y$ is the measurement vector, and $G$ is the contribution matrix expressing the sensitivity of the retrieval to the measurement. The derivative of the measurement vector (the 


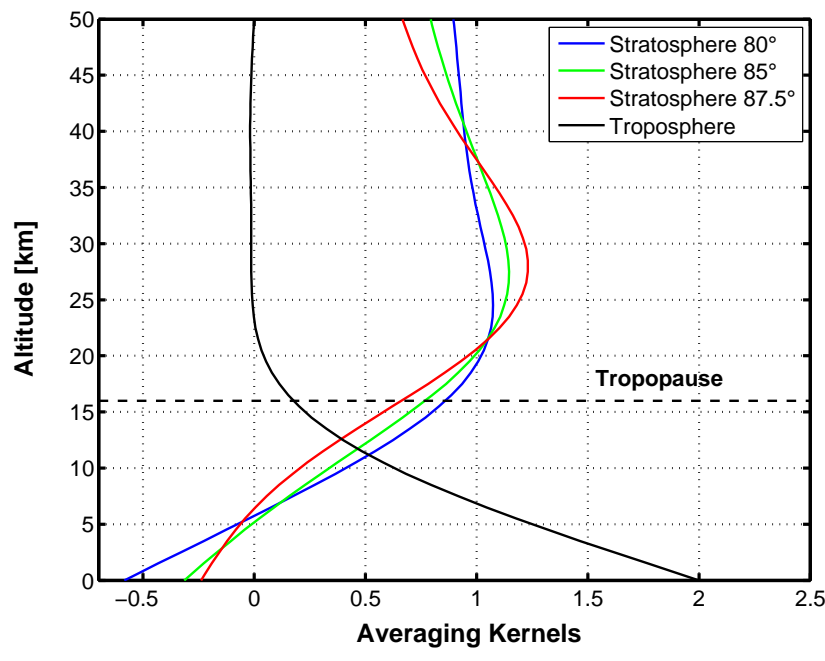

Fig. 3. Typical examples of ground-based averaging kernels for stratospheric $\mathrm{BrO}$ columns (at $80^{\circ}, 85^{\circ}$ and $87.5^{\circ} \mathrm{SZA}$ ) and for tropospheric $\mathrm{BrO}$ columns (see text).

slant column densities) with respect to the $\mathrm{BrO}$ vertical profiles have been determined by a perturbation method using the radiative transfer model.

Figure 3 shows the tropospheric and stratospheric VCDs averaging kernels (AK) calculated according to Eq. (3) for three representative values of the SZA $\left(80^{\circ}, 85^{\circ}\right.$ and $\left.87.5^{\circ}\right)$. The AK values represent the way the retrieval smooths the respective partial column profiles (for a $1 \mathrm{~km}$ layer around the altitude given in the y-axis). It can be deduced from Fig. 3 that the inverted tropospheric columns are largely independent from the simultaneously inverted stratospheric columns. The high value of the tropospheric AK nearby the surface is related to the enhanced sensitivity of the off-axis observations in this altitude region. On the contrary, the stratospheric averaging kernels peak in the stratosphere around the maximum of $\mathrm{BrO}$ concentration profiles.

\subsection{Error analysis}

The contributions to the total retrieval uncertainty are divided into three categories: (1) random errors caused by measurement noise and $\mathrm{BrO}$ variability (2) errors affecting the slant column density in a systematic way, and (3) errors due to remaining uncertainties in the modeling and representation of the atmosphere, affecting the air mass factors.

We investigate the errors affecting the SCDs and the AMFs. A careful estimate of the uncertainties is especially crucial at high SZA. Indeed, a large part of the information used to separate the stratospheric and tropospheric $\mathrm{BrO}$ columns comes from measurements at high SZA. The uncertainties affecting the SCDs (random and systematic errors) as well as the AMFs are largest at low sun.

Measurement and modeling uncertainties have been estimated by means of sensitivity studies. As an example, the results for zenith-sky observations are displayed in Table 1 for typical low, medium and high solar zenith angles (respectively $70^{\circ}, 85^{\circ}$ and $90^{\circ} \mathrm{SZA}$ ). The scatter of the measured DSCDs has been found to be relatively constant from month to month. Hence average values of 1.2, 1.9 and $3.4 \times 10^{13} \mathrm{molec} / \mathrm{cm}^{2}$ have been attributed to random error sources, respectively, for the three representative SZAs. These values are also consistent with the one-sigma uncertainties derived from the DOAS fitting procedure. DSCDs systematic errors are mainly introduced by uncertainties on the absorption cross-sections of the molecules included in the analysis, leading to mutually correlated DOAS results.

In order to estimate the errors due to absorption crosssections and their cross-correlations, one approach is to consider the cross-sections as forward model parameters of the DOAS retrieval. Following the formalism introduced by Rodgers (2000), the forward model parameter error of the retrieval can be derived from the quoted uncertainties on the cross-sections used in the DOAS analysis. Based on literature data and sensitivity tests using various data sources, the following uncertainty figures have been adopted for $\mathrm{BrO}$ : $8 \%, \mathrm{NO}_{2}: 3 \%, \mathrm{O}_{3}: 3 \%, \mathrm{O}_{4}: 5 \%, \mathrm{HCHO}: 5 \%$ and Ring effect interferences: $5 \%$. In addition to cross-sections, other sources of systematic errors can be identified, like the errors linked to calibration or other additional instrumental uncertainties. As already pointed out in Sect. 3.1, the use of the DOAS approximation by which slant columns are assumed to be constant within the spectral fitting window, can also be a significant source of systematic uncertainty. Using the optimal fitting window derived in Sect. 3.1, sensitivity studies suggest that these sources of uncertainties do not contribute more than 5\% to the total SCD error. Considering absolute slant columns (i.e. corrected for the $\mathrm{BrO}$ residual amount in the reference spectrum), a constant additional error of \pm 0.5 $10^{13} \mathrm{molec} / \mathrm{cm}^{2}$ has been introduced, following estimates described in Sect. 4.2. From Table 1, it must be emphasized that SCDs errors are largely dominated at twilight by systematic biases mainly introduced by uncertainties on the absorption cross-sections.

In addition to the error analysis described above, an alternative study has been performed to estimate systematic errors due to absorption cross-sections uncertainties. It consisted in running test retrievals using different sources of crosssections available from the literature and investigating the resulting variability of the retrieved $\mathrm{BrO}$ slant columns. Uncertainties empirically estimated in this way were found to be in good agreement with the values (see Table 1) deduced from the approach based on the Rodgers (2000) formalism.

Once the total uncertainties on the measurements has been estimated for each elevation angle and for all solar zenith angles, the resulting uncertainties on the retrieved stratospheric and tropospheric $\mathrm{BrO}$ vertical columns are given by simple error propagation (see Table 2). The next step is to evaluate the errors on the AMFs. For small SZA $\left(<85^{\circ}\right)$, the stratospheric AMF can be satisfactorily approached by a 
Table 1. Summary error budget for BrO slant column densities (random, systematic and RSCD error sources) and air mass factors in zenith-sky geometry, for three representative solar zenith angles.

\begin{tabular}{lccc}
\hline & \multicolumn{3}{c}{ Solar zenith angle } \\
Slant column density error $\left(\times 10^{13} \mathrm{molec} / \mathrm{cm}^{2}\right)$ & $70^{\circ}$ & $85^{\circ}$ & $90^{\circ}$ \\
\hline Random & 1.2 & 1.9 & 3.4 \\
Systematic bias & 0.7 & 4 & 6.8 \\
Residual slant column density (RSCD) & 0.5 & 0.5 & 0.5 \\
Total $\left(\times 10^{13}\right.$ molec $\left./ \mathrm{cm}^{2}\right)$ & 1.5 & 4.5 & 7.6 \\
Total $(\%)$ & 13 & 23 & 24 \\
\hline & \multicolumn{3}{c}{ Solar zenith angle } \\
Air mass factor error $(\%)$ & $70^{\circ}$ & $85^{\circ}$ & $90^{\circ}$ \\
\hline Stratosphere: AM & 1.5 & 1.5 & 3.5 \\
Stratosphere: PM & 1.5 & 1.5 & 2.5 \\
Troposphere & 5 & 15 & 5 \\
\hline
\end{tabular}

geometrical calculation. The error on the stratospheric AMF is therefore negligible. In contrast at high SZA, the stratospheric AMF is highly dependent on the BrO concentration at the bulk altitude for Rayleigh scattering, the latter increasing with the SZA (see e.g. Sinnhuber et al., 2002). Hence accurate modeling of the photochemistry is needed to evaluate correctly the stratospheric AMFs. To a large extent, the stratospheric $\mathrm{BrO}$ concentration is controlled by $\mathrm{NO}_{2}$ through the termolecular reaction $\mathrm{BrO}+\mathrm{NO}_{2}+\mathrm{M}$. In order to minimize errors due to the interplay between $\mathrm{BrO}$ and $\mathrm{NO}_{2}$, the photochemical simulations have been constrained using $\mathrm{NO}_{2}$ profiles derived from simultaneous zenith-sky observations in the visible region (Hendrick et al., 2004). Nevertheless remaining uncertainties in other aspects of the photochemical model calculations may have a substantial impact on the results. Hence sensitivity studies have been carried out in order to estimate the impact of the uncertainties on main reaction rate constants, following the work presented in Sinnhuber et al. (2002). The stratospheric AMF errors have been estimated by the standard deviation of the ensemble of AMFs generated by varying independently the reaction rate constants. Results from this analysis are summarized in Table 1 .

The estimation of the errors on the tropospheric AMFs is difficult, mainly due to the following two reasons: (1) the treatment of the radiative transfer down to the surface strongly depends on the aerosol loading as well as the (unknown) BrO vertical distribution, and (2) the diurnal variation of the tropospheric $\mathrm{BrO}$ content might have to be taken into account. Since substantial uncertainties accompany these parameters, several hypotheses have been made here. Some of these will be justified later on in the discussion (see Sect. 4). As a baseline for our retrievals, we have assumed that the aerosol content was small (justified in Sect. 4.1) and that the bulk of the tropospheric BrO concen- tration was mainly located in the free-troposphere (justified in Sect. 4.4).

A rough estimate of the tropospheric AMF error has been obtained by varying input $\mathrm{BrO}$ profiles in the RTM calculations. Gaussian profiles of various heights [5$8 \mathrm{~km}$ ] and widths [1-4 km] have been used to this purpose. Corresponding tropospheric $\mathrm{BrO}$ AMFs show a root mean square deviation of less than $15 \%$ as indicated in Table 1. For the diurnal variation, we assume that the known photochemistry of $\mathrm{BrO}$ in the lower stratosphere constitutes a reasonable proxi for the free troposphere (Schofield et al., 2004a, b). In reality, one may expect the tropospheric $\mathrm{BrO}$ amount to vary in response to e.g. emissions from the oceans, meteorological conditions, changes in photolysis rates (e.g. due to clouds), and other physical and chemical processes. It is difficult to comprehensively account for all these effects in a realistic way. However, in order to roughly estimate the order of magnitude of errors related to diurnal variation effects, we have considered two extreme cases: (1) the baseline tropospheric $\mathrm{BrO}$ diurnal variation, where basically the $\mathrm{BrO}$ concentration drops to zero from noon to late twilight and (2) the case where tropospheric $\mathrm{BrO}$ has no diurnal variation at all (which is very unlikely). We assume that in reality the tropospheric $\mathrm{BrO}$ diurnal variation lies somewhere in between these two cases. Test retrievals considering these two scenarios resulted in minor differences on the inverted $\mathrm{BrO}$ columns (approximately $1 \times 10^{12} \mathrm{molec} / \mathrm{cm}^{2}$ ).

The main sources of uncertainties on the inverted $\mathrm{BrO}$ VCDs (obtained by propagation of the error discussed above) are summarized in Table 2 for morning conditions. Although not reported here, similar results have been derived for afternoon observations. As can be seen, stratospheric VCDs have largest uncertainties $(>30 \%)$ at low sun and at very high sun, while errors are kept in the range of $20 \%$ for intermediate values of the SZA. The absolute error on the tropospheric 
Table 2. Summary error budget for morning stratospheric $\mathrm{BrO}$ and tropospheric $\mathrm{BrO}$ columns.

\begin{tabular}{lcccccc}
\hline & \multicolumn{7}{c}{ Stratospheric VCD error $\left(\times 10^{13}\right.$ molec $\left./ \mathrm{cm}^{2}\right)$} & Tropospheric \\
Error source & 45 & 80 & 85 & 87.5 & 92.5 & VCD error \\
\hline Slant column densities & 0.5 & 0.3 & 0.3 & 0.3 & 0.1 & 0.3 \\
Stratospheric AMFs & $<0.1$ & $<0.1$ & $<0.1$ & $<0.1$ & $<0.1$ & $<0.1$ \\
Tropospheric AMFs & 0.6 & 0.4 & 0.3 & 0.2 & 0.1 & 0.4 \\
Total VCD error $\left(\times 10^{13}\right.$ molec $\left./ \mathrm{cm}^{2}\right)$ & 0.8 & 0.5 & 0.4 & 0.4 & 0.1 & 0.5 \\
Total VCD error $(\%)$ & 30 & 21 & 17 & 17 & 33 & 46 \\
\hline
\end{tabular}

BrO VCD, mainly dominated by uncertainties on the tropospheric AMFs and on the measured SCDs, is estimated to be about $45 \%$.

\section{Results and discussion}

To simplify the discussion, we first restrict the analysis to clear-sky measurement days when the transfer of the scattered radiation can be simulated with best accuracy. We focus on the determination of three key parameters that control the accuracy of the target BrO VCD products; namely the aerosol extinction, the residual $\mathrm{BrO}$ slant column density in the reference spectrum and the shape of the tropospheric $\mathrm{BrO}$ profile. Results are then discussed with regard to our current understanding of the bromine chemistry in both the stratosphere and the troposphere. In a second step, a simplified version of the inversion algorithm is applied to the whole series of measurements from from August 2004 until June 2005, and the consistency of the retrieved BrO columns is investigated in comparison with coincident satellite observations from SCIAMACHY.

\subsection{Determination of the aerosol settings}

The light path of photons scattered in the lower atmosphere is strongly dependent on the aerosol loading, especially nearby the surface. A good estimate of the aerosol extinction profile is thus needed for the calculation of the tropospheric $\mathrm{BrO}$ AMFs. This is especially true for small elevation angles, which in principle have the longest light paths. As suggested by Wagner et al. (2004) and Frieß et al. (2006), multi-axis observations of the oxygen dimmer $\mathrm{O}_{4}$ can be used to deduce the aerosol extinction profile. The analysis of aerosol properties has to be limited to measurements without significant cloud influence, since $\mathrm{O}_{4}$ absorptions are greatly affected by clouds. Out of the complete 2004 data set (i.e. approximately six months of measurements), seven days could be selected as fully clear sky days (day numbers 242, 246, 253, 271, $272,326,346$ ), based on an analysis of the diurnal variation of the measured $\mathrm{O}_{4}$ absorptions at all elevation angles. For all these days, $\mathrm{O}_{4}$ absorptions were found to follow the same smooth diurnal evolution, indicating similar aerosols scenarios. In Fig. 4., the $\mathrm{O}_{4}$ DSCDs averaged on the selected days (and on a $2.5^{\circ}$ SZA bin grid) are represented as a function of SZA for morning and afternoon observations. In order to reproduce the $\mathrm{O}_{4}$ observations, a set of $\mathrm{O}_{4}$ AMFs were computed for each elevation angle and for different aerosol extinction profiles. Radiative transfer calculations were initialized using vertical profiles of $\mathrm{O}_{4}$, pressure, temperature and $\mathrm{O}_{3}$ characteristic of tropical regions, according to the AFGL atmospheric constituent profiles data base (Anderson et al., 1986). The aerosol extinction profile was then varied until good agreement was found for the $\mathrm{O}_{4}$ verticals columns derived from all viewing elevations. This procedure is similar to the one proposed and applied in Heckel et al. (2005). As demonstrated in Fig. 5, the optimal aerosol extinction profile corresponds to an aerosol visibility (Middleton, 1952) of $80 \mathrm{~km}$ with an enhanced maritime aerosol load (extinction $\sim 0.2 \mathrm{~km}^{-1}$ ) introduced into a $100 \mathrm{~m}$ thick layer above the surface. $\mathrm{O}_{4}$ VCDs retrieved assuming an aerosol visibility of $40 \mathrm{~km}$ are also shown for comparison purpose.

\subsection{Determination of the residual slant column density}

In this work, the zenith-sky and off-axis measurements have been processed using a fixed zenith reference spectrum selected at minimum solar zenith angle $\left(28.7^{\circ} \mathrm{SZA}\right)$ on 2 September 2004. As mentioned earlier, the introduction of an extra fitting parameter for the residual slant column (RSCD in Eq. 1) can be a source of uncertainty for the retrieved stratospheric and tropospheric BrO VCDs. In order to minimize this error and stabilize the retrieval process, the residual slant column density is therefore determined prior to the inversion process so that absolute slant columns (rather than differential SCDs) can be fitted.

The residual slant column density has been estimated from an average of clear days measurements (selected in Sect. 4.1), assuming that the $\mathrm{BrO}$ field is stable enough to allow meaningful interpretation of the resulting averaged SCDs. This assumption will be further verified in Sect. 4.5. 


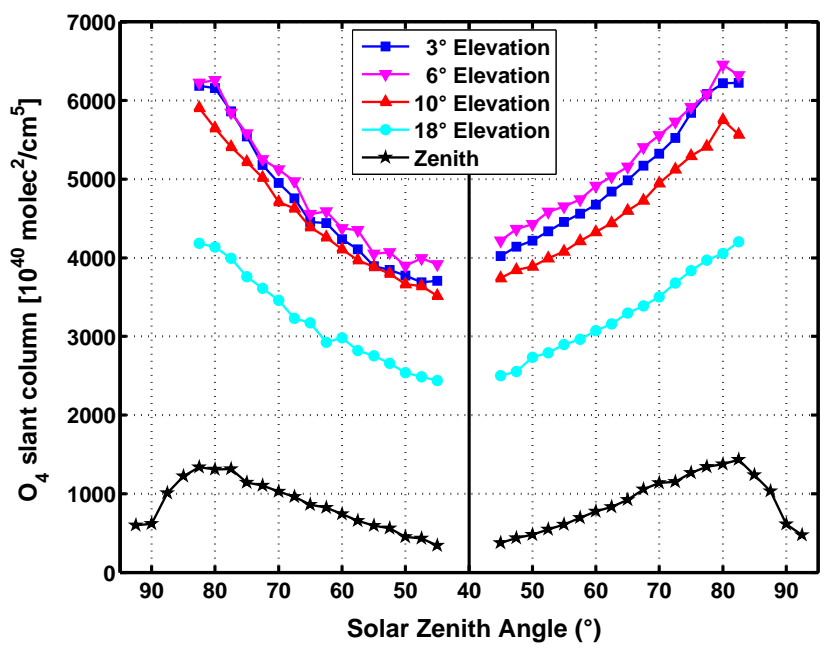

Fig. 4. Differential slant columns of $\mathrm{O}_{4}$ measured for different elevation angles as a function of the SZA. Morning and afternoon measurements are displayed together. The $\mathrm{O}_{4}$ DSCDs have been averaged from a selection of 7 clear-sky days and binned on a grid of $2.5^{\circ} \mathrm{SZA}$.

Based on Eq. (1), the RSCD is treated as an additional parameter in the $\mathrm{BrO}$ VCDs retrieval. In order to minimize the impact of uncertainties related to the diurnal variation, systematic measurement errors or AMFs modeling errors (all becoming important at twilight), only the measurements corresponding to solar zenith angles lower than $85^{\circ}$ are considered. This also reduces the number of fitted parameters and therefore stabilizes the inversion for the RSCD. Using this approach, residual slant column densities of $6.42 \times 10^{13}$ and $6.37 \times 10^{13} \mathrm{molec} / \mathrm{cm}^{2}$ are retrieved, respectively from morning and afternoon measurements. The (small) differences in the retrieved RSCDs can be attributed to a large extend to the propagation of the measurement errors into the BrO VCDs retrieval. An error analysis according to Sect. 3.3., leads to a best estimate of $6.4 \pm 0.5 \times 10^{13} \mathrm{molec} / \mathrm{cm}^{2}$. Furthermore, this value is found to be consistent with the re-calculated RSCD based on the retrieved VCDs evaluated at the time of the reference spectrum.

\subsection{Clear-sky results}

The inversion technique described in Sect. 3.2 has been applied to the restricted data set of clear sky measurements, also used for the aerosol and residual $\mathrm{BrO}$ column determination. The resulting retrieval fit results are displayed in Fig. 6. For the sake of clarity, only afternoon results are represented for a limited number of viewing directions. As can be seen, the modeled SCDs are consistent with the observations, for all SZA and viewing angles. In Fig. 7, the differences between the measured and the modeled slant column densities are shown as a function of the SZA, for the various elevation angles. A comparison with the results of the algorithm assum-

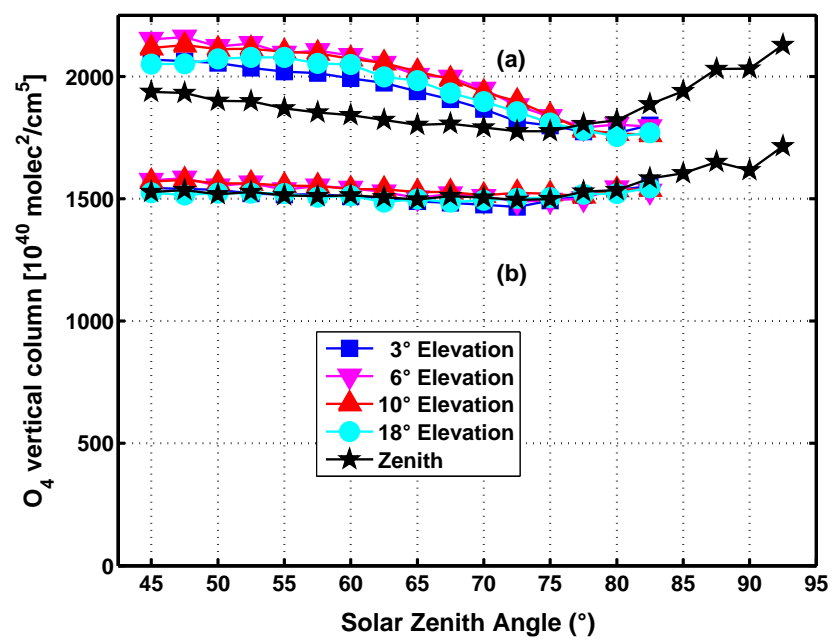

Fig. 5. Vertical columns of $\mathrm{O}_{4}$ calculated for all viewing directions based on AMFs for two aerosols scenarios, as a function of SZA: aerosol extinction profiles corresponding to (a) a visibility of $40 \mathrm{~km}$ and (b) a visibility of $80 \mathrm{~km}$ with a higher aerosol load (extinction: $\sim 0.2 \mathrm{~km}^{-1}$ ) added in a thin layer close to the surface $(0-100 \mathrm{~m})$.

ing that $\mathrm{BrO}$ would only be present in the stratosphere clearly demonstrates the need to include both a stratospheric and a tropospheric $\mathrm{BrO}$ contribution in the inversion process. The level of agreement between the elevation directions observations strongly depends on the hypothesis made for the tropospheric BrO profile as part of the tropospheric AMFs calculations. This will be addressed in the next section, where the relevance of using a free-tropospheric profile as derived in Fitzenberger et al. (2000) is tested and discussed.

The retrieved $\mathrm{BrO}$ vertical columns and their respective retrieval uncertainties (based on the error analysis developed in Sect. 3.4) are displayed in Fig. 8, for both morning and afternoon conditions.

\subsubsection{Tropospheric $\mathrm{BrO}$}

Tropospheric $\mathrm{BrO}$ vertical columns (at $80^{\circ}$ of SZA) of about 1.1 and $1.2 \times 10^{13} \mathrm{molec} / \mathrm{cm}^{2}$ are retrieved independently from morning and afternoon measurements separately, with a mean uncertainty of about $0.5 \times 10^{13} \mathrm{molec} / \mathrm{cm}^{2}$. This represents approximately one third of the total $\mathrm{BrO}$ column retrieved at the same SZA and therefore supports the existence of significant sources of inorganic bromine in the tropical troposphere.

Such results are roughly consistent with mid-latitude tropospheric $\mathrm{BrO}$ background values of $1-3 \times 10^{13} \mathrm{molec} / \mathrm{cm}^{2}$ obtained from GOME, ground-based and balloon measurements (e.g. Van Roozendael et al., 2002). Similarly GOME measurements over the equatorial pacific using a technique contrasting cloudy and clear-sky scenes conclude to a background tropospheric $\mathrm{BrO}$ column of $1-4 \times 10^{13} \mathrm{molec} / \mathrm{cm}^{2}$ (Richter et al., 2002). The combined use of SCIAMACHY 


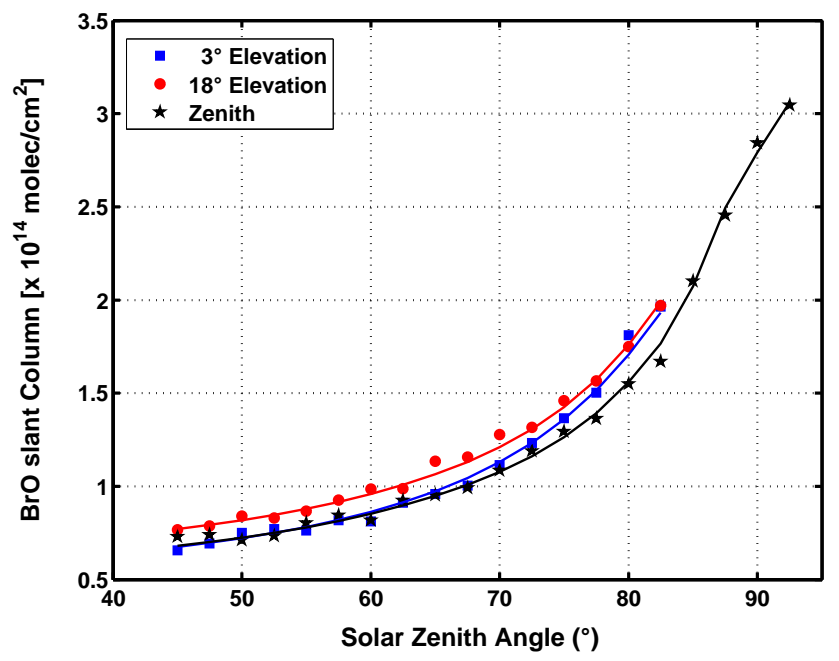

Fig. 6. Measured and modeled afternoon $\mathrm{BrO}$ slant column densities, as a function of the SZA for 3 elevation viewing angles $\left(3^{\circ}\right.$, $18^{\circ}$ and zenith).

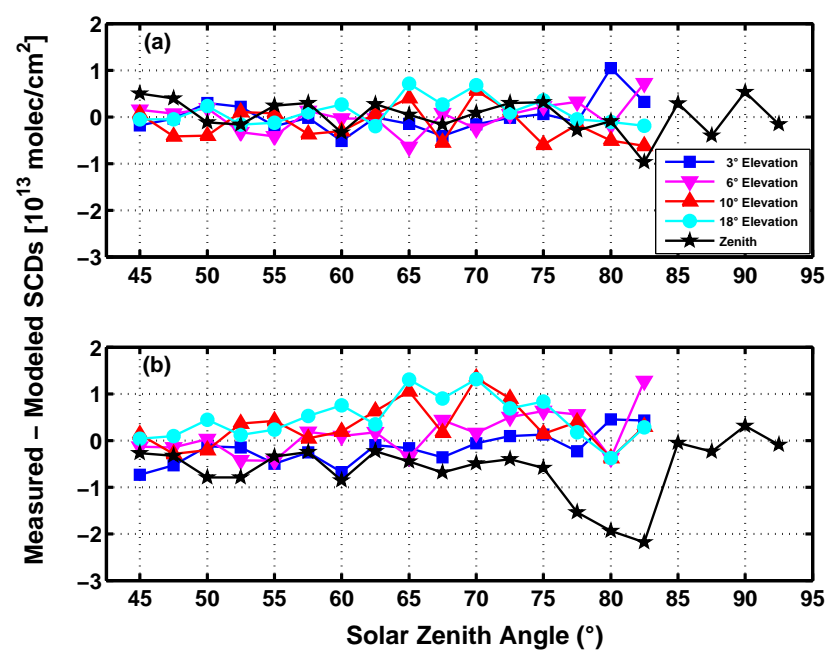

Fig. 7. Retrieval residuals for averaged clear-sky data (see text), as a function of the SZA. The modeled SCDs are subtracted from the measured SCDs, for all viewing directions. Two different assumptions are made for the $\mathrm{BrO}$ vertical repartition: (a) $\mathrm{BrO}$ is present in both stratosphere and troposphere, (b) $\mathrm{BrO}$ is entirely located in the stratosphere.

(onboard the ENVISAT satellite) nadir and limb observations also suggests an average global tropospheric BrO column below $15 \mathrm{~km}$ of about $2-4 \times 10^{13} \mathrm{molec} / \mathrm{cm}^{2}$ (Sinnhuber et al., 2005). On the other hand, significantly smaller tropospheric $\mathrm{BrO}$ columns in the range of $0.2 \pm 0.4 \times 10^{13} \mathrm{molec} / \mathrm{cm}^{2}$ are derived from the combined use of direct sun and zenith sky measurements at the Southern mid-latitude site of Lauder (Schofield et al., 2004a).

More specifically, BrO measurements in the tropical troposphere have been very sparse and in fact limited to few

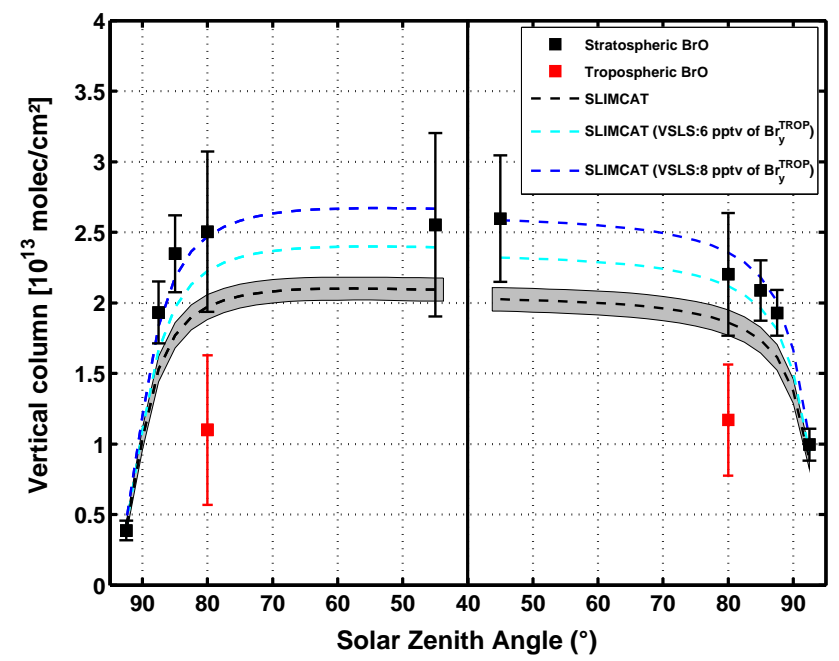

Fig. 8. Morning and afternoon stratospheric and tropospheric $\mathrm{BrO}$ vertical columns retrieved from averaged clear-sky data. The dashed lines correspond to stratospheric columns obtained from photochemical model simulations initialized with SLIMCAT fields having different contributions from the very short-lived bromine species (VSLS): (black) 6 pptv, (cyan) 6 pptv and (blue) 8 pptv directly injected at the tropopause. The shaded area corresponds to the range of uncertainties associated to reaction rate constants.

studies. More recently at Nairobi, measurements similar to those reported here (Fietkau et al., 2007) conclude to tropospheric $\mathrm{BrO}$ columns in the range from 4 to $7.5 \times 10^{12}$ molecules $/ \mathrm{cm}^{2}$ in closer agreement with Reunion Island results although still slightly smaller. The difference could possibly be explained by the fact that the profile inversion used at Nairobi loses sensitivity above $6 \mathrm{~km}$ of altitude, while the different stratosphere-troposphere approach used in our study maintain better sensitivity higher up in the troposphere (see averaging kernels in Fig. 3). Beyond retrieval issues, the possibility of an added tropospheric $\mathrm{BrO}$ content at Reunion Island due to influx from sea salt aerosol might also be considered (Fietkau et al., 2007).

\subsubsection{Stratospheric $\mathrm{BrO}$}

The retrieved stratospheric $\mathrm{BrO}$ vertical columns and their respective error estimates (at the chosen SZAs of $45^{\circ}, 80^{\circ}$, $85^{\circ}, 87.5^{\circ}$ and $92.5^{\circ}$ ) are displayed in Fig. 8. A strong diurnal variation is observed as a result of the photochemically evolving interplay between $\mathrm{BrO}$ and its nighttime reservoirs $\left(\mathrm{HOBr}, \mathrm{BrONO}_{2}\right)$ (e.g. Lary et al., 1996a, b). From Fig. 8., higher stratospheric $\mathrm{BrO}$ columns are found at sunrise than at sunset, for the reference SZAs of $80^{\circ}$ and $85^{\circ}$. The rapid increase of $\mathrm{BrO}$ at sunrise is due to the fast photolysis of $\mathrm{HOBr}$, which is produced during the night due to heterogeneous conversion of bromine nitrate by hydrolysis on sulfate aerosols. The decrease of $\mathrm{BrO}$ during the day is related to the increase of stratospheric $\mathrm{NO}_{2}$, which in turn influences 
the bromine partitioning through the termolecular reaction $\mathrm{BrO}+\mathrm{NO}_{2}+\mathrm{M}$.

The stratospheric column results of the photochemical model (initialized with the chemical fields from the SLIMCAT model) are also shown in Fig. 8 (black dashed line). The diurnal evolution of the measured columns is properly captured by the model, providing strong evidence that the stratospheric bromine photochemistry is well understood and represented. It can also be seen however that modeled vertical columns are substantially smaller than the retrieved stratospheric columns. The shaded region around the modeled vertical columns indicates the impact (at the $1 \sigma$ level) of the uncertainties of the rate constants for the most important reactions. One possible explanation for the underestimation of the BrO columns by the model run can be found in the way bromine sources (including the short-lived species) have been treated in the relatively old SLIMCAT version used for the present work (run D in Feng et al., 2007). These are represented using a single effective source of $\mathrm{CH}_{3} \mathrm{Br}$ (with a mixing ratio of $21.2 \mathrm{pptv}$ at the surface). Since in reality the short-lived source gases are decomposed faster than methyl bromide, the $\mathrm{Br}_{\mathrm{y}}$ mixing ratio could be substantially underestimated by the model, especially in the lower stratosphere, which might have an important impact on the integrated $\mathrm{BrO}$ vertical column. In order to investigate this effect, we considered the extreme case where the short-lived species are totally converted in $\mathrm{Br}_{\mathrm{y}}$ at the tropopause. This was achieved by applying a simple offset to the SLIMCAT $\mathrm{Br}_{\mathrm{y}}$ mixing ratio profile (scaled for the contribution of the long-lived bromine sources only). The stratospheric BrO columns resulting from this test scenario are displayed in Fig. 8 for contributions of $6 \mathrm{pptv}$ (cyan dashed line) and $8 \mathrm{pptv}$ (blue dashed line) from the decomposition of the short-lived bromine species. The value of 8 pptv can be considered as a plausible upper limit for the contribution of the bromine short-lived species, in agreement with recent studies (Pfeilsticker et al., 2000; Salawitch et al., 2005; Schofield et al., 2006; Dorf et al., 2006a, b; Sioris et al., 2006). This also confirms the findings of Feng et al. (2007), who have tested different methods of implementing the bromine source gases in the SLIMCAT model and found that the agreement between model and balloon data is significantly improved when having explicitly the short-lived source gases.

In order to gain better insight into the consistency between our retrieved stratospheric $\mathrm{BrO}$ content and data from the literature, the stratospheric $\mathrm{BrO}$ profiling algorithm of Hendrick et al. $(2004,2007)$ based on the optimal estimation technique (Rodgers, 2000), has been applied to the zenithsky clear-sky observations performed at Reunion Island. Figure 9a displays a comparison of the resulting $\mathrm{BrO}$ profile with those obtained from the balloon-borne SAOZ instrument during the late afternoon ascent of the balloon at $75^{\circ}-80^{\circ} \mathrm{SZA}$ at the same latitude $\left(22.4^{\circ} \mathrm{S}, 49^{\circ} \mathrm{W}\right)$ in Brazil in November 1997 (Pundt et al., 2002), and January-February 2004 during the Hibiscus campaign (F. Goutail et al., personal communi-
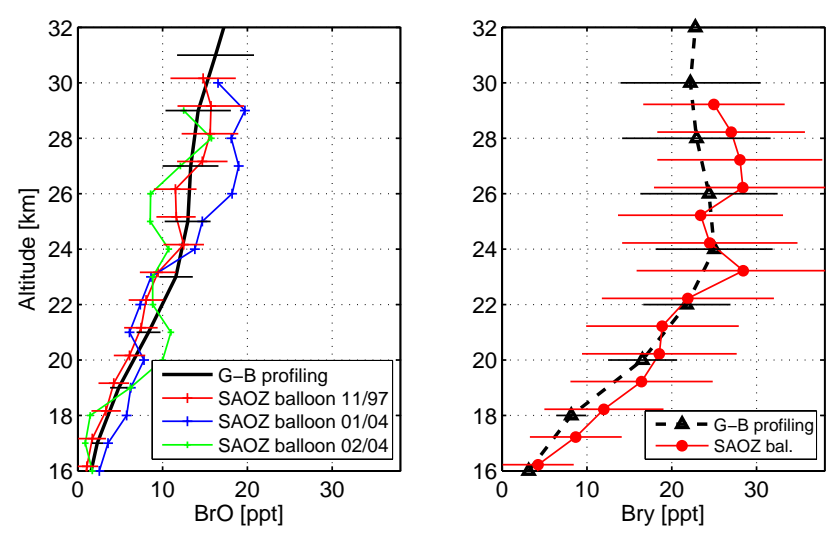

Fig. 9. Retrieved stratospheric $\mathrm{BrO}$ profile compared to tropical $\mathrm{SAOZ}$ balloon $\mathrm{BrO}$ profiles (left plot). Profile of $\mathrm{Br}_{\mathrm{y}}$ inferred from ground-based $\mathrm{BrO}$ profile compared to the $\mathrm{SAOZ}$ balloon $\mathrm{Br}_{\mathrm{y}}$ profile at $22^{\circ} \mathrm{S}$, November 1997 (right plot).

cation). Since SAOZ balloon measurements are performed during evening twilight in ascent mode (typically around 86$87^{\circ} \mathrm{SZA}$ ) the ground-based $\mathrm{BrO}$ profile was retrieved from afternoon observations at the appropriate SZA. Although significant changes can be observed in the stratosphere from one flight to another a reasonable agreement is found between ground-based and balloon profiles at the same latitude. This is especially true for the flight in November 1997.

From the stratospheric BrO profile, it is also possible to derive a stratospheric inorganic bromine profile based on estimates of the $\mathrm{BrO} / \mathrm{Br}_{\mathrm{y}}$ ratio given by the photochemical model. Figure $9 \mathrm{~b}$ shows the $\mathrm{Br}_{\mathrm{y}}$ profile deduced from our retrieved tropical $\mathrm{BrO}$ profile. A good agreement is found with the $\mathrm{Br}_{y}$ vertical distribution derived by Salawitch et al. (2005) based on SAOZ observations.

From these results, one concludes to a total inorganic bromine content of about 23 pptv, which suggests a contribution from several short-lived organic bromine sources to the stratospheric inorganic bromine budget, in agreement with studies from Pfeilsticker et al. (2000) and Salawitch et al. (2005).

\subsection{Determination of the tropospheric $\mathrm{BrO}$ vertical distri- bution}

Since the light path through the troposphere strongly depends on both SZA and viewing elevation angle, only an appropriate tropospheric BrO vertical profile in the AMFs calculation will lead to a good agreement between the modeled SCDs and the measured SCDs, for all viewing angles. An illustration of the sensitivity of the multi-axis DOAS observations for an absorber located at different altitudes is given in Fig. 10, in the form of air mass factor (AMF) curves represented for two different values of the SZA $\left(60^{\circ}\right.$ and $\left.80^{\circ}\right)$. By comparing Figs. 6 and 10, it can be easily deduced that our observations do not show evidence for large amounts 


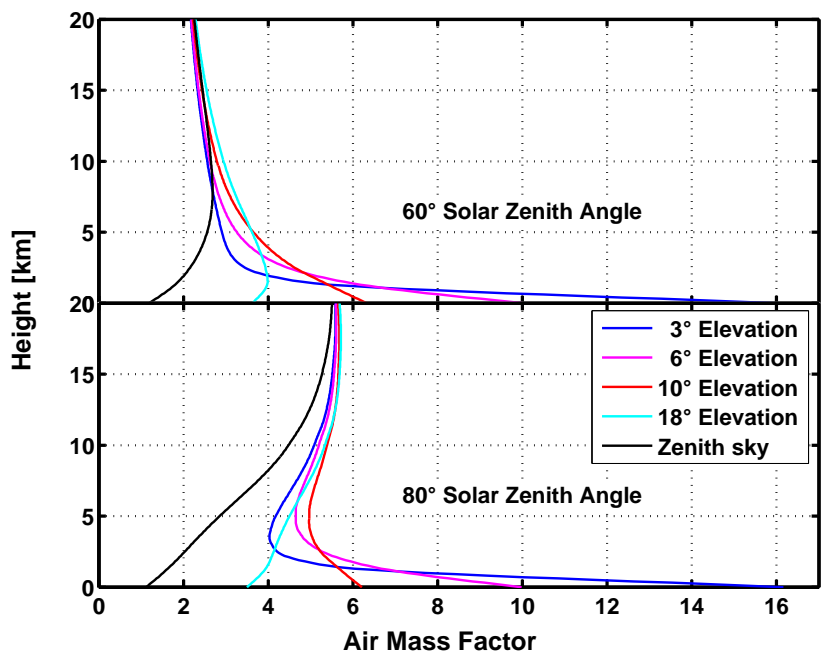

Fig. 10. Height dependence of the sensitivity to $\mathrm{BrO}$ for the different viewing directions at $60^{\circ} \mathrm{SZA}$ (upper plot) and at $80^{\circ} \mathrm{SZA}$ (lower plot). The value on the $\mathrm{x}$-axis is the air mass factor for a $1 \mathrm{~km}$ layer positioned around the height given on the $\mathrm{y}$-axis.

of $\mathrm{BrO}$ in the boundary layer. Indeed this would require a systematic and pronounced increase of the measured $\mathrm{BrO}$ SCDs towards low elevation angles, which is definitely not observed. Based on the error budget of the retrieved $\mathrm{BrO}$ slant column densities (summarized in Table 1), one cannot exclude a possible enhancement in the range of approximately $1 \times 10^{13} \mathrm{molec} / \mathrm{cm}^{2}$, which translate to an upper limit of $0.5 \mathrm{pptv}$ for $\mathrm{BrO}$ being possibly present in the oceanic boundary layer at Reunion Island.

If one assumes a $\mathrm{BrO}$ profile peaking higher up in the troposphere around $6-7 \mathrm{~km}$, Fig. 10 indicates that at low SZA $\left(60^{\circ}\right)$ the AMF is almost the same at $3^{\circ}$ elevation and at zenith, a sizeable enhancement of the sensitivity being only obtained at $18^{\circ}$ of elevation. On the contrary at larger SZA $\left(80^{\circ}\right)$, larger AMF values are found at both $3^{\circ}$ and $18^{\circ}$ elevation. This characteristic behavior of the elevation angles sensitivities for a free-tropospheric profile is consistently observed in the measured slant columns in Fig. 6. In order to gain information on the vertical distribution of $\mathrm{BrO}$ in the troposphere, sensitivity tests have been made on the average of the 7 clear days of measurements (selected in Sect. 4.3) and have consisted in varying bulk altitudes and full widths at half maximum (FWHM) of Gaussian tropospheric profiles used to calculate tropospheric AMFs. The best residuals were obtained for a concentration profile peaking at $6 \mathrm{~km}$ altitude with a FWHM of $2 \mathrm{~km}$, for both morning and afternoon observations. A maximum of 2 to $5 \mathrm{pptv}$ in the free troposphere is deduced from our estimate of the tropospheric BrO column $\left(1.1 \pm 0.5 \times 10^{13} \mathrm{molec} / \mathrm{cm}^{2}\right)$. These results are roughly in agreement with the tropospheric $\mathrm{BrO}$ profile measurements reported in Fitzenberger et al. (2000), based on balloon borne DOAS observations performed at
Kiruna, Sweden. In contrast MAXDOAS profile inversion results recently obtained above Nairobi, Kenya (Fietkau et al., 2007) suggest a bulk tropospheric BrO layer located between 2 and $3 \mathrm{~km}$ altitude, hence slightly lower than found at Reunion Island.

This apparent discrepancy might be related to the fact that the inversion technique used in the Fietkau et al. (2007) study was essentially limited to the lowest $6.5 \mathrm{~km}$. In addition, Nairobi is a continental station located at relatively high altitude $(1600 \mathrm{~m})$ likely not influenced by bromine emission from oceanic origin.

\subsection{Seasonal variation}

Since clear-sky observations do not show evidence for sizeable amounts of $\mathrm{BrO}$ being present in the lowest troposphere, one can safely expect that slant column measurements will generally be weakly affected by the presence of low altitude clouds and/or particles. Hence we decided to apply our inversion technique on a daily basis in order to derive information of the seasonal cycle of the retrieved stratospheric and tropospheric $\mathrm{BrO}$ vertical columns.

In order to somehow stabilize the inversion and allow its application to day-to-day observations inherently noisier than averages considered so far, the algorithm has been slightly simplified with respect to the scheme presented in Sect. 3.2. Instead of retrieving the diurnal variation of the stratospheric VCD for each day, it was decided to fix this variation based on the clear-sky analysis obtained in Sect. 4.3. Accordingly a single stratospheric BrO vertical column is derived from the inversion process, for a given reference SZA $\left(80^{\circ}\right.$ was selected here), together with the tropospheric BrO column. This approach applied separately to morning and evening observations was found to represent the best compromise between information content and retrieval noise on a daily basis.

The resulting time-series of stratospheric and tropospheric $\mathrm{BrO}$ columns (hence retrieved at $80^{\circ} \mathrm{SZA}$ at both sunrise and sunset) are displayed in Fig. 11, for the entire observation period. Only vertical columns corresponding to retrieval residuals lower than $2 \times 10^{13} \mathrm{molec} / \mathrm{cm}^{2}$ were considered in this analysis. This threshold has been chosen in order to reject unrealistic measurements, contaminated by thick clouds or affected by spectral artifact due e.g. to anomalously large $\mathrm{O}_{4}$ absorption. The retrieved stratospheric and tropospheric $\mathrm{BrO}$ columns are on average in excellent agreement with the values derived from the averaged clear-sky observations (Sect. 4.3) and show no noticeable seasonal variation. This result is somewhat in contradiction with expectations based on photochemical considerations valid for tropical latitudes. Model simulations of the noon or near twilight $\left(\mathrm{SZA}<80^{\circ}\right)$ stratospheric BrO column at Reunion-Island indeed show a small seasonality, with an amplitude smaller than $10 \%$. Such an effect however lies within the uncertainties of our retrieved stratospheric $\mathrm{BrO}$ columns, which moreover do not 


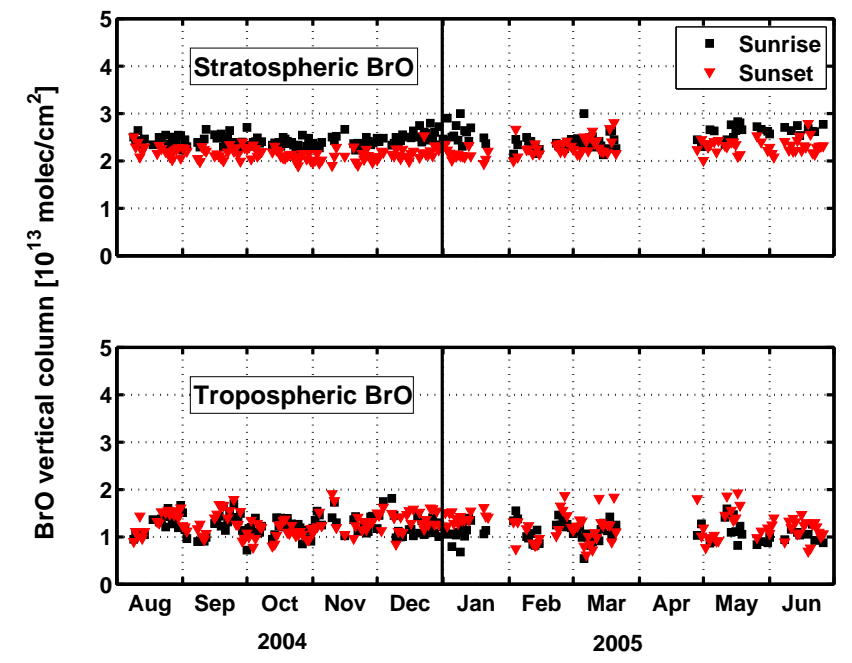

Fig. 11. Time-series of stratospheric (top) and tropospheric (bottom) $\mathrm{BrO}$ columns retrieved for $80^{\circ} \mathrm{SZA}$, displayed separately for sunrise (squares) and sunset (triangles).

cover a complete annual cycle. Longer observational time series would certainly help characterizing better the seasonal variations.

The seasonal photochemical response of stratospheric $\mathrm{BrO}$ to changes in $\mathrm{NO}_{2}$ concentration can in fact be studied with larger sensitivity when considering twilight observations above $80^{\circ} \mathrm{SZA}$. To this aim, comparisons of modeled and measured $\mathrm{BrO} 90-80^{\circ}$ differential slant columns were performed. Under these conditions, results show that both simulations and measurements present a significant seasonal cycle which follows the expected anti-correlation with $\mathrm{NO}_{2}$, i.e. a minimum in summer and a maximum in winter. The observations also reproduces the diurnal cycle well, with PM values larger than AM ones, as reported in other studies (Sinnhuber et al., 2002; Fietkau et al., 2007).

\subsection{Comparison with SCIAMACHY total column BrO ob- servations}

Onboard the ENVISAT platform, the SCanning Imaging Absorption spectroMeter for Atmospheric CHartographY (SCIAMACHY) measures the sunlight reflected, backscattered or transmitted by the Earth's atmosphere in the ultraviolet, visible and near-infrared spectral regions (Bovensmann et al., 1999). Among other geophysical data products, the vertical column of BrO can be derived from SCIAMACHY nadir measurements, using DOAS algorithms similar to those applied to ground-based measurements reported here. Prior to SCIAMACHY, BrO columns were also measured by the GOME instrument onboard ERS-2. However the diffuser plate used for irradiance measurements on the GOME instrument exhibits a time dependent interference pattern, which correlates with $\mathrm{BrO}$ and prevents reliable independent $\mathrm{BrO}$

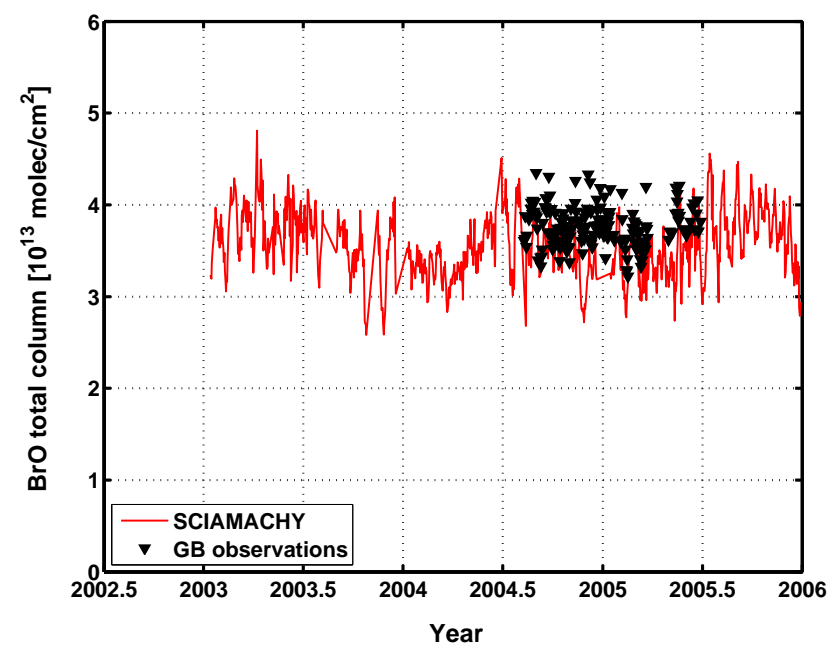

Fig. 12. Total BrO columns retrieved from ground-based DOAS observations at Reunion-Island and from SCIAMACHY nadir observations averaged in a zonal band of 10 degrees centered at the latitude of the ground-based station.

column measurements to be obtained with this instrument, therefore making it unsuitable for an assessment of the tropical BrO content (e.g. Richter et al., 2002). To overcome this problem, SCIAMACHY was equipped with a quasi-volume diffuser plate on the back of its azimuth scan mirror (ASM) with the aim to provide irradiance measurements suitable for minor trace gases retrievals. SCIAMACHY BrO columns used in this work were analysed using daily sun irradiance from the ASM diffuser plate, according to retrieval settings described in Van Roozendael et al. (2004). To optimize the consistency with ground-based retrieval, SCIAMACHY BrO vertical columns were evaluated using AMFs calculated according to the $\mathrm{BrO}$ vertical distribution retrieved at Reunion Island.

Figure 12 presents the comparison between SCIAMACHY BrO vertical columns extracted from daily fields in a latitude zone of $+/-5$ degrees around Reunion Island and the ground-based $\mathrm{BrO}$ total vertical columns, photochemically adjusted at the time of the satellite overpass using the $\mathrm{BrO}$ diurnal variation determined in Sect. 4.3. Considering the uncertainties on both satellite and ground-based $\mathrm{BrO}$ measurements, the agreement obtained is highly satisfying. Since the ground-based and satellite total column analysis are essentially independent from each other (the dependency of the satellite nadir AMF on the shape of the BrO profile being in practice very small), these results consolidate our confidence in both ground-based and satellite estimates of the tropical BrO column. They also indirectly consolidate our estimate of the tropospheric $\mathrm{BrO}$ column, which as already stated represents a significant part (one third) of the total $\mathrm{BrO}$ column. 


\section{Conclusions}

Tropospheric and stratospheric $\mathrm{BrO}$ columns were derived using a new double-column inversion method, accounting for the transfer of the radiation in the atmosphere and the $\mathrm{BrO}$ diurnal variation. This was applied to combined zenith-sky and off-axis ground-based UV-visible spectroscopic measurements at Reunion Island. Tropospheric BrO columns of $1.1 \pm 0.5 \times 10^{13} \mathrm{molec} / \mathrm{cm}^{2}$ were retrieved, generally in agreement with estimations sparsely available from the literature. Sensitivity tests demonstrate a substantial contribution from the free-troposphere (around $6 \mathrm{~km}$ altitude) to the tropospheric $\mathrm{BrO}$ vertical column, however our observations do not support the existence of significant amounts of $\mathrm{BrO}$ in the tropical boundary layer. These results are in agreement with recent studies suggesting that tropical biogenic sources of short-lived organic bromine species might be converted into active bromine in the free-troposphere by mechanisms involving heterogeneous reactions possibly on ice crystals and water droplets (Fitzenberger et al., 2000).

The retrieved stratospheric columns show a diurnal variation coherent with photochemical model calculations based on recently updated rates. From a comparison between the retrieved stratospheric $\mathrm{BrO}$ columns and results from the 3D chemical-transport model SLIMCAT, one concludes that a satisfactory agreement can only be achieved by assuming an important delivery of $\mathrm{Br}_{\mathrm{y}}$ (of about 6-8 pptv) in the stratosphere possibly produced by short-lived bromine organic compounds, rapidly converted into inorganic forms at the tropical tropopause. Based on the inversion of the stratospheric BrO profile according to Hendrick et al. (2007), a total stratospheric inorganic bromine content of about $23 \mathrm{pptv}$ is inferred, which further strengthens the likely importance of short-lived bromine species as an important contribution to the $\mathrm{Br}_{\mathrm{y}}$ budget. Total $\mathrm{BrO}$ columns are found to be in agreement with SCIAMACHY observations in a latitudinal band centered around Reunion Island. These results consolidate our confidence in both ground-based and satellite estimates of the tropical $\mathrm{BrO}$ columns.

Acknowledgements. The authors wish to thank J.-P. Decuyper (technical support at BIRA), J.-M. Metzger (technical support at Reunion Island), M. Chipperfield (for providing us with SLIMCAT data), A. Richter and F. Wittrock (for providing us with a Windows version of SCIATRAN). The balloon flights in 2004 in Brazil were part of the EC FP5 HIBISCUS project (EVK2-2001-000111). This research was financially supported by the EC FP6 SCOUT-O3 (505390-GOCE-CT-2004), AGACC projects and the Belgium Prodex NOy-Bry projects.

Edited by: T. Wagner

\section{References}

Aliwell, S. R., Van Roozendael, M., Johnston, P. V., Richter, A., Wagner, T., et al.: Analysis for BrO in zenith-sky spectra: An intercomparison exercise for analysis improvement, J. Geophys. Res., 107, D140, doi:10.1029/2001JD000329, 2002.

Anderson, G. P., Clough, S. A., Kneizys, F. X., Chetwynd, J. H., and Shettle, E. P.: AFGL atmospheric constituent profiles (0$120 \mathrm{~km})$, Tech. Rep. AFGL-TR-86-0110, Air Force Geophys. Lab., Hascom Air Force Base, Mass., 1986.

Arpag, K. H., Johnston, P. V., Miller, H. L., Sander, R. W., and Solomon, S.: Observations of stratospheric BrO column over Colorado, 40 N, J. Geophys. Res., 99, 8175-8181, 1994.

Bobrowski, N., Höninger, G., Galle, B., and Platt, U.: Detection of bromine monoxide in a volcanic plume, Nature, 423, 273-276, 2003.

Bogumil, K., Orphal, J., Homann, T., Voigt, S., Spietz, P., Fleischmann, O. C., Vogel, A., Hartmann, M., Bovensmann, H., Frerik, J., and Burrows, J. P.: Measurements of molecular absorption spectra with the SCIAMACHY Pre-Flight Model: Instrument characterization and reference spectra for atmospheric remote sensing in the $230-2380 \mathrm{~nm}$ region, J. Photochem. Photobiol. A, 157, 167-184, 2003.

Bovensmann, H., Burrows, J. P., Buchwitz, M., Frerick, J., Noël, S., Rozanov, V. V., Chance, K. V., and Goede, A. P. H.: SCIAMACHY: Mission objectives and Measurement Modes, J. Atmos. Sci., 56, 127-150, 1999.

Carpenter, L. J. and Liss, P. S.: On temperature sources of bromoform and other reactive organic bromine gases, J. Geophys. Res. D., 105(D16), 20 539-20 547, 2000.

Chipperfield, M. P.: Multiannual simulations with a threedimensional chemical transport model, J. Geophys. Res., 104(D1), 1781-1805, 1999.

Chipperfield, M. P.: New Version of the TOMCAT/SLIMCAT OffLine Chemical Transport Model: Intercomparison of Stratospheric Tracer Experiments, Q. J. Roy. Meteor. Soc., 132, 11791203, doi:10.1256/qj.05.51, 2006.

Dorf, M., Bösch, H., Butz, A., Camy-Peyret, C., Chipperfield, M., Engel, A., Goutail,F., Grunow, K., Hendrick, F., Hrechanyy, S., Naujokat, B., Pommereau, J.-P., Van Roozendael, M., Sioris, C., Stroh, F., Weidner, F., and Pfeilsticker, K.: Balloon-borne stratospheric BrO measurements: Intercomparisons with ENVISAT/SCIAMACHY BrO limb profiles, Atmos. Chem. Phys., 6, 2483-2501, 2006a.

Dorf, M., Butler, J. H., Butz, A., Camy-Peyret, C., Chipperfield, M. P., Kritten, L., Montzka, S. A., Simmes, B., Weidner, F., and Pfeilsticker, K.: Long-term observations of stratospheric bromine reveal slow down in growth, Geophys. Res. Lett., 33, L24803, doi:10.1029/2006GL027714, 2006b.

Errera, Q. and Fonteyn, D.: Four-dimensional variational chemical assimilation of CRISTA stratospheric measurements, J. Geophys. Res., 106(D11), 12 253-12 265, 2001.

Feng, W., Chipperfield, M. P., Dorf, M., Pfeilsticker, K., and Ricaud, P.: Mid-latitude ozone changes: studies with a 3-D CTM forced by ERA-40 analyses, Atmos. Chem. Phys., 7, 2357-2369, 2007 , http://www.atmos-chem-phys.net/7/2357/2007/.

Fietkau, S., Medeke, T., Richter, A., Sheode, N., Sinnhuber, B.-M., Wittrock, F., Theys, N., Van Roozendael, M., and Burrows, J. P.: Ground-based measurements of tropospheric and stratospheric 
bromine monoxide above Nairobi $\left(1^{\circ} \mathrm{S}, 36^{\circ} \mathrm{E}\right)$, Atmos. Chem. Phys. Discuss., 7, 6527-6555, 2007,

http://www.atmos-chem-phys-discuss.net/7/6527/2007/.

Fish, D. J., Jones, R. L., and Strong, E. K.: Mid-latitude observations of the diurnal variation of stratospheric BrO, J. Geophys. Res., 100, 18 863-18 871, 1995.

Fitzenberger, R., Bösch, R., Camy-Peyret, C., Chipperfiel, M. P., Harder, H., Platt, U., Sinnhuber, B.-M., Wagner, T., and Pfeilsticker, K.: First profile measurements of tropospheric BrO, Geophys. Res. Lett., 27, 2921-2924, 2000.

Frieß, U., Hollwedel, J., König-Langlo, G., Wagner, T., and Platt, U.: Dynamics and chemistry of tropospheric bromine explosion events in the Antarctic coastal region, J. Geophys. Res., 109, D06305, doi:10.1029/2003JD004133, 2004.

Frieß, U., Monks, P. S., Remedios, J. J., Rozanov, A., Sinreich, R., Wagner, T., and Platt, U.: MAX-DOAS $\mathrm{O}_{4}$ measurements: A new technique to derive information on atmospheric aerosols: 2. Modeling studies, J. Geophys. Res., 111, D14203, doi:10.1029/2005JD006618, 2006.

Grainger, J. F. and Ring, J.: Anomalous Fraunhofer line profiles, Nature, 193, 762, 1962.

Greenblatt, G. D., Orlando, J. J., Burkholder, J. B., and Ravishankara, A. R.: Absorption measurements of oxygen between 330 and 1140 nm, J. Geophys. Res., 95, 18 577-18 582, 1990.

Hausmann, M. and Platt, U.: Spectroscopic measurement of bromine oxide and ozone in the high Arctic during Polar Sunrise Experiment 1992, J. Geophys. Res., 99, 25 399-25 414, 1994.

Hebestreit, K., Stutz, J., Rosen, D., Matveiv, V., Peleg, M., Luria, M., and Platt, U.: DOAS measurements of tropospheric bromine oxide in mid-latitudes, Science, 283, 55-57, 1999.

Heckel, A., Richter, A., Tarsu, T., Wittrock, F., Hak, C., Pundt, I., Junkermann, and Burrows, J. P.: MAX-DOAS measurements of formaldehyde in the Po-Valley, Atmos. Chem. Phys., 5, 909-918, 2005 , http://www.atmos-chem-phys.net/5/909/2005/.

Hendrick, F., Barret, B., Van Roozendael, M., Boesch, H., Butz, A., De Mazière, M., Goutail, F., Hermans, C., Lambert, J.-C., Pfeilsticker, K., and Pommereau, J.-P.: Retrieval of nitrogen dioxide stratospheric profiles from ground-based zenith-sky UVvisible observations: validation of the technique through correlative comparisons, Atmos. Chem. Phys., 4, 2091-2106, 2004, http://www.atmos-chem-phys.net/4/2091/2004/.

Hendrick, F., Van Roozendael, M., Kylling, A., Petritoli, A., Rozanov, A., Sanghavi, S., Schofield, R., von Friedeburg, C., Wagner, T., Wittrock, F., Fonteyn. D., and De Mazière, M.: Intercomparison exercise between different radiative transfer models used for the interpretation of ground-based zenith-sky and multiaxis DOAS observations, Atmos. Chem. Phys., 6, 93-108, 2006, http://www.atmos-chem-phys.net/6/93/2006/.

Hendrick, F., Van Roozendael, M., Chipperfield, M. P., Dorf, M., Goutail, F., Yang, X., Fayt, C., Hermans, C., Pfeilsticker, K., Pommereau, J.-P., Pyle, J. A., Theys, N., and De Mazière, M.: Retrieval of stratospheric and tropospheric $\mathrm{BrO}$ profiles and columns using ground-based zenith-sky DOAS observations at Harestua, $60^{\circ} \mathrm{N}$, Atmos. Chem. Phys. Discuss., 7, 8663-8708, 2007 ,

http://www.atmos-chem-phys-discuss.net/7/8663/2007/.

Hönninger, G. and Platt, U.: Observations of $\mathrm{BrO}$ and its vertical distribution during surface ozone depletion at Alert, Atmos. En- viron., 36, 2481-2489, 2002.

Koelemeijer, R. B. A., de Haan, J. F., and Stammes, P.: A database of spectral surface reflectivity in the range $335-772 \mathrm{~nm}$ derived from 5.5 years of GOME observations, J. Geophys. Res.-Atm., 108(D2), 4070, doi:10.1029/2002JD002429, 2003.

Kreher, K., Johnston, P. V., Wood, S. W., Nardi, B., and Platt, U.: Ground-based measurements of tropospheric and stratospheric BrO at Arrival Heights, Antartica, Geophys. Res. Lett., 24, 3021-3024, 1997.

Kurucz, R. L., Furenlid, I., Brault, J., and Testerman, L.: Solar flux atlas from $296 \mathrm{~nm}$ to $1300 \mathrm{~nm}$, National Solar Observatory Atlas No. 1, 1984

Lary, D. J.: Gas phase atmospheric bromine photochemistry, J. Geophys. Res., 101, 1505-1516, 1996a.

Lary, D. J., Chipperfield, M. P., Toumi, R., and Lenton, T.: Heterogeneous atmospheric bromine photochemistry, J. Geophys. Res., 101, 1489-1504, 1996b.

Lary, D. J.: Halogens and the chemistry of the free troposphere, Atmos. Chem. Phys., 5, 227-237, 2005, http://www.atmos-chem-phys.net/5/227/2005/.

Leser, H., Höninger, G., and Platt, U.: Max-DOAS measurements of $\mathrm{BrO}$ and $\mathrm{NO}_{2}$ in the marine boundary layer, Geophys. Res. Lett., 30, 1537, doi:10.1029/2002GL015811, 2003.

Mayer, B. and Kylling, A.: Technical note: The libRadtran software package for radiative transfer calculations - description and examples of use, Atmos. Chem. Phys., 5, 1855-1877, 2005, http://www.atmos-chem-phys.net/5/1855/2005/.

Meller, R. and Moortgat, G. K.: Temperature dependence of the absorption cross-sections of formaldehyde between 223 and $323 \mathrm{~K}$ in the wavelength range $225-375 \mathrm{~nm}$, J. Geophys. Res., 105, 7089-7101, 2000.

Middleton, W. E. K.: Vision through the Atmosphere, Univ. of Toronto Press, Toronto, 1952.

Platt, U.: Differential optical absorption spectroscopy (DOAS), Air Monit. By Spectr. Techniques, edited by: Sigrist, M. W., Chemical Analysis Series, 127, 27-84, John Wiley \& Sons, Inc., 1994.

Pfeilsticker, K., Sturges, W. T., Bösch, H., Camy-Peyret, C., Chipperfield, M. P., Engel, A., Fitzenberger, R., Müller, M., Payan, S., and Sinnhuber, B.-M.: Lower stratospheric organic and inorganic bromine budget for the arctic winter 1998/99, Geophys. Res. Lett., 27, 3305-3308, 2000.

Preston, K. E., Jones, R. L., and Roscoe, H. K.: Retrieval of $\mathrm{NO}_{2}$ profiles from ground-based UV-visible measurements - method and validation, J. Geophys. Res., 102, 19 089-19097, 1997.

Pundt, I., Van Roozendael, M., Wagner, T., Richter, A., Chipperfield, M., Burrows, J. P., Fayt, C., Hendrick, F., Pfeilsticker, K., Platt, U., and Pommereau, J.-P.: Simultaneous UV-vis measurementsof $\mathrm{BrO}$ from balloon, satellite and ground: implications for tropospheric BrO, in Proc. Fifth European Symp. on polar stratospheric ozone 1999, Air Poll. Res. Report 73, EUR 19340, European Commission, Brussels, Belgium, edited by: Harris, N. R. P., Guirlet, M., and Amanatidis, G. T., p. 316-319, 2000.

Pundt, I., Pommereau, J.-P., Chipperfield, M. P., Van Roozendael, M., and Goutail, F.: Climatology of the stratospheric BrO vertical distribution by balloon-borne UV-visible spectrometry, J. Geophys. Res., 107(D24), 4806, doi:10.1029/2002JD002230, 2002.

Richter, A., Wittrock, F., Eisinger, M., and Burrows, J. P.: GOME observations of tropospheric BrO in Northern Hemi- 
spheric spring and summer 1997, Geophys. Res. Lett., 25, 26832686, 1998.

Richter, A., Eisinger, M., Ladstätter-Weissenmayer, A., and Burrows, J. P.: DOAS zenith-sky observations, 2, seasonal variation of $\mathrm{BrO}$ over Bremen (53 N) 1994-1995, J. Atmos. Chem., 32, 83-99, 1999.

Richter, A., Wittrock, F., Ladstätter-Weissenmayer, A., and Burrows, J. P.: GOME measurements of stratospheric and tropospheric BrO, Adv. Space Res., 29, 1667-1672, 2002.

Rodgers, C. D.: Inverse Methods for Atmospheric Sounding, Theory and Practice, World Scientific Publishing, Singapore-NewJersey-London-Hong Kong, 2000.

Rozanov, A., Rozanov, V., and Burrows, J. P.: A numerical radiative transfer model for a spherical planetary atmosphere: Combined differential integral approach involving the Piccard iterative approximation, J. Quant. Spectrosc. Radiat. Trans., 69, 491-512, 2001.

Salawitch, R. J., Weisenstein, D. K., Kovalenko, L. J., Sioris, C. E., Wennberg, P. O., Chance, K., Ko, M. K. W., and McLinden, C. A.: Sensitivity of ozone to bromine in the lower stratosphere, Geophys. Res. Lett., 32, L05811, doi:10.1029/2004GL021504, 2005.

Salawitch, R. J.: Atmospheric chemistry: biogenic bromine, Nature, 439, 275-277, 2006.

Sander, S. P., Friedl, R. R., Ravishankara, A. R., et al.: Chemical Kinetics and Photochemical Data for Use in Atmospheric Studies, Evaluation no. 15, NASA JPL Publication no. 06-2, 2006.

Schofield, R., Kreher, K., Connor, B. J., Johnston, P. V., Thomas, A., Shooter, D., Chipperfield, M. P., Rodgers, C. D., and Mount, G. H.: Retrieved tropospheric and stratospheric BrO columns over Lauder, New Zealand., J. Geophys. Res., 109, D14304, doi:10.1029/2003JD004463, 2004a.

Schofield, R., Connor, B. J., R., Kreher, K., Johnston, P. V., and Rodgers, C. D.: The retrieval of profile and chemical information from ground-based UV-visible spectroscopic measurements, J. Quant. Spectrosc. Radiat. Trans., 86, 115-131, 2004b.

Schofield, R., Johnston, P. V., Thomas, A., Kreher, K., Connor, B. J., Wood, S., Shooter, D., Chipperfield, M. P., Richter, A., von Glasow, R., and Rodgers, C. D.: Tropospheric and stratospheric BrO columns over Arrival Heights, Antartica, 2002, J. Geophys. Res., 111, D22310, doi:10.1029/2005JD007022, 2006.

Simpson, W. R., von Glasow, R., Riedel, K., Anderson, P., Ariya, P., Bottenheim, J., Burrows, J., Carpenter, L., Frieß, U., Goodsite, M. E., Heard, D., Hutterli, M., Jacobi, H.-W., Kaleschke, L., Neff, B., Plane, J., Platt, U., Richter, A., Roscoe, H., Sander, R., Shepson, P., Sodeau, J., Steffen, A., Wagner, T., and Wolff, E.: Halogens and their role in polar boundary-layer ozone depletion, Atmos. Chem. Phys., 7, 4375-4418, 2007, http://www.atmos-chem-phys.net/7/4375/2007/.

Sinnhuber, B.-M., Arlander, D. W., Bovensmann, H., et al.: Comparison of measurements and model calculations of stratospheric bromine monoxide, J. Geophys. Res., 107(D19), 4398, doi:10.1029//2001JD000940, 2002.

Sinnhuber, B.-M., Rozanov, A., Sheode, N., Afe, O. T., Richter, A., Sinnhuber, M., Wittrock, F., and Burrows, J. P.: Global observations of stratospheric bromine monoxide from SCIAMACHY, Geophys. Res. Lett., 32, L20810, doi:10.1029/2005GL023839, 2005.

Sioris, C. E., Kovalenko, L. J., McLinden, C. A., Salawitch, R.
J., Van Roozendael, M., Goutail, F., Dorf, M., Pfeilsticker, K., Chance, K., von Savigny, C., Liu, X., Kurosu, T. P., Pommereau, J.-P., Bösch, H., and Frerick, J.: Latitudinal and vertical distribution of bromine monoxide in the lower stratosphere from Scanning Imaging Absorption Spectrometer for Atomspheric Chartography limb scattering measurements, J. Geophys. Res., 111, D14301, doi:10.1029/2005JD006479, 2006.

Vandaele, A.-C., Hermans, C., Simon, P. C., Carleer, M., Colin, R., Fally, S., Mérienne, M.-F., Jenouvrier, A., and Coquart, B.: Measurements of the NO2 absorption cross-section from $42000 \mathrm{~cm}^{-1}$ to $10000 \mathrm{~cm}^{-1}(238-1000 \mathrm{~nm})$ at $220 \mathrm{~K}$ and 294 K, J. Quant. Spectrosc. Radiat. Trans., 59, 171-184, 1997.

Van Roozendael, M., Fayt, C., Lambert, J.-C., Pundt, I., Wagner, T., Richter, A., and Chance, K.: Development of a bromine oxide product from GOME, European Symposium on Atmosph. Measurements from Space, ESA WPP-161, 543-547, 1999.

Van Roozendael, M., Wagner, T., Richter, A., Pundt, I., Arlander, D., Burrows, J. P., Chipperfield, M., Fayt, C., Johnston, P. V., Lambert, J.-C., Kreher, K., Pfeilsticker, K., Platt, U., Pommereau, J.-P., Sinnhuber, B.-M., Tornkvist, K. K., and Wittrock, F.: Intercomparison of $\mathrm{BrO}$ measurements from ERS-2 GOME, ground-based and balloon platforms, Adv. Space Res., 29, 16611666, 2002.

Van Roozendael, M., De Smedt, I., Fayt, C., Wittrock, F., Richter, A., and Afe, O.: First validation of SCIAMACHY BrO columns, in Proc. Second Workshop on the Atmospheric Chemistry Validation of ENVISAT (ACVE-2), Frascati, Italy, 3-7 May 2004.

von Glasow, R., von Kuhlmann, R., Lawrence, M. G., Platt, U., and Crutzen, P. J.: Impact of reactive bromine chemistry in the troposphere, Atmos. Chem. Phys., 4, 2481-2497, 2004, http://www.atmos-chem-phys.net/4/2481/2004/.

Vountas, M., Rozanov, V. V., and Burrows, J. P.: Ring effect: Impact of rotational raman scattering on radiative transfer in earth's atmosphere, J. Quant. Spectrosc. Radiat. Trans., 60, 943-961, 1998.

Wagner, T. and Platt, U.: Satellite mapping of enhanced BrO concentrations in the troposphere, Nature, 395, 486-490, 1998.

Wagner, T., Dix, D., von Friedeburg, C., Friess, U., Sanghavi, S., Sinreich, R., and Platt, U.: MAX-DOAS $\mathrm{O}_{4}$ measurements: A new technique to derive information an atmospheric aerosols-Principles and information content, J. Geophys. Res., 109, D22205, doi:10.1029/2004JD004904, 2004.

Wamsley, P. R., Elkins, J. W., Fahey, D. W., Dutton, G. S., Volk, C. M., Myers, R. C., Montzka, S. A., Butler, J. H., Clarke, A. D., Fraser, P. J., Steele, L. P., Lucarelli, M. P., Atlas, E. L., Schauffler, S. M., Blake, D. R., Rowland, F. S., Sturges, W. T., Lee, J. M., Penkett, S. A., Engel, A., Stimpfle, R. M., Chan, K. R., Weisenstein, D. K., Ko, M. K. W., and Salawitch, R. J.: Distribution of halon-1211 in the upper troposphere and lower stratosphere and the 1994 total bromine budget, J. Geophys. Res., 103(D1), 1513-1526, 1998

WMO: Global ozone research and monitoring project, in: Scientific Assessment of Ozone Depletion: 1998, Rep. 44, Geneva, 1998.

WMO: Global ozone research and monitoring project, in: Scientific Assessment of Ozone Depletion: 2002, Rep. 47, Geneva, 2003.

Wilmouth, D. M., Hanisco, T. F., Donahue, N. M., and Anderson, J. G.: Fourier transform ultraviolet spectroscopy of the $\mathrm{A}_{3 / 2}^{2 \Pi} \leftarrow \mathrm{X}_{3 / 2}^{2 \Pi}$ transition of BrO, J. Phys. Chem. A., 103, 8935$8945,1999$. 
Wittrock, F., Oetjen, H., Richter, A., Fietkau, S., Medeke, T., Rozanov, A., and Burrows, J. P.: Max-DOAS measurements of atmospheric trace gases in Ny-Ålesund - Radiative transfer studies and their application, Atmos. Chem. Phys., 4, 955-966, 2004, http://www.atmos-chem-phys.net/4/955/2004/.
Yang, X., Cox, R. A., Warwick, N. J., Pyle, J. A., Carver, G. D., O'Connor, F. M., and Savage, N. H.: Tropospheric bromine chemistry and its impact on ozone: A model study, J., Geophys. Res., 110, D23311, doi:10.1029/2005JD006244, 2005. 